\title{
Research \\ Collaborative Engagement of Local and Traditional Knowledge and Science in Marine Environments: A Review
}

\author{
$\underline{\text { Thomas F. Thornton }}^{1}$ and Adela Maciejewski Scheer $^{2}$
}

\begin{abstract}
Local and traditional ecological knowledge (LTK) is increasingly recognized as an important component of scientific research, conservation, and resource management. Especially where there are gaps in the scientific literature, LTK can be a critical source of basic environmental data; this situation is particularly apparent in the case of marine ecosystems, about which comparatively less is known than terrestrial ones. We surveyed the global literature relating to the LTK of marine environments and analyzed what knowledge has been collected and with what aims and results. A large proportion of LTK which has been documented by researchers consists of species-specific information that is important for traditional resource use. However, knowledge relating to marine ecology, environmental change, and contemporary resource management practices is increasingly emphasized in the literature. Today, marine LTK is being used to provide historical and contemporary baseline information, suggest stewardship techniques, improve conservation planning and practice, and to resolve management disputes. Still, comparatively few studies are geared toward the practicalities of developing a truly collaborative, adaptive, and resilient management infrastructure that is embracive of modern science and LTK and practices in marine environments. Based on the literature, we thus suggest how such an infrastructure might be advanced through collaborative projects and "bridging" institutions that highlight the importance of trust-building and the involvement of communities in all stages of research, and the importance of shared interest in project objectives, settings (seascapes), and outcomes.
\end{abstract}

Key Words: adaptive comanagement; collaborative research; collaborative resource management; ecological monitoring; environmental change; historical ecology; local and traditional knowledge (LTK); marine conservation; marine ecology; marine ecosystems

\section{INTRODUCTION}

Over the past several decades, as concerns about declines in local habitats, species, and livelihoods have increased, the potential contributions of local and traditional knowledge (LTK) to ecosystem research and management have been increasingly recognized. To date, LTK studies have been diverse and often interdisciplinary. However, there are few examples of works that bring together the literature across these fields in the marine context (see Johannes and Neis 2007 for one broad review). Given the increasing concern about marine ecosystems in relation to climate change, overfishing, pollution, and other anthropogenic impacts, coupled with humanity's comparative ignorance of the sea in relation to terrestrial environments, interest in marine LTK can be expected to increase. Furthermore, conceptualizations of marine ecosystems inherent in LTK may have increasing relevance to critical adaptation and conservation tasks, such as identifying historical baselines and environmental change, establishing restoration and sustainability targets for species, increasing the resilience of marine social-ecological systems, and improving coastal zone and marine spatial planning and fisheries management.

As a contribution to this effort, we review both the aims and substantive content of work to date on marine LTK, in order to highlight key themes and critical gaps, and to address the role of marine LTK in marine social-ecological systems. We conclude that while empirical studies of LTK are numerous, few engage local knowledge systems and indigenous epistemologies enough to achieve a respectful synthesis or integration (Agrawal 1995, Hamilton and Walter 1999, Nadasdy 1999, Cruikshank 2001, Agrawal 2002, Simpson 2004, Cruikshank 2005, Nadasdy 2005, Wilson et al. 2006, Berkes 2009b). Genuine collaborative projects are rare and often insufficient in scope and depth to address critical, multiscale conservation, adaptation, and management issues facing coastal seascapes today. We explore how this situation might be remedied through collaborative research and management projects that enhance genuine coproduction of knowledge and collaborative implementation of that knowledge in policy. Finally we suggest how diverse, timetested, traditional knowledge; stewardship principles; and technologies embedded in LTK systems may be applicable to the human adaptation and resilience needs of a complex, changing environment (Berkes et al. 1995). Before turning to the review of the aims and substantive content of LTK studies, we first briefly set out key definitions and how marine LTK may be best understood.

\section{Marine LTK as a body of knowledge}

To understand its cultural context and interrelationships, LTK is best conceptualized as a body or system of knowledge rather than a mere assemblage of facts. Foremost, this involves understanding how LTK, including related skills, is 
communicated and transmitted in situ and in vivo as part of the exigencies of maritime life (Aporta and Higgs 2005, Berkes and Turner 2006, Crona and Bodin 2006, Foale 2006b, Murray et al. 2006, Akyeampong 2007, Palmer and Wadley 2007, Poepoe et al. 2007, Reyes-Garcia et al. 2007, Alessa et al. 2008, Bonny and Berkes 2008, Pearce et al. 2011). Secondly, it involves examining the structure and distribution of knowledge within communities (Felt 1994, Ruddle 1994, Olsson and Folke 2001, Crona 2006, Knudsen 2008) and how it corresponds to broader differentiations and power relations (Crona and Bodin 2010). For example, Chapman (1987) focuses particularly on the different fishing practices and ecological knowledge held by men and women in Oceania, which are distinct but complementary. At a broader scale, the question of how ecological knowledge systems interact at different decision-making scales has also been examined (Evans 2010), as have the impacts of the broader social and political context on the ability of marine tenure systems to adapt and support well-being (Coulthard 2011). Local tenure systems - such as those in the Fiji Local Marine Management Areas network, which are based on traditional i qoliqoli (fishing territories) (Fiji Locally Managed Marine Areas Network 2011) — have also been successfully aggregated, in order to appropriately scale LTK and participation to marine ecosystem governance needs.

Valdés-Pizzini and García-Quijano (2009:163) collected LTK, at the level of the individual fisher, on habitats, species, and the relationships between these two variables, while also exploring fishers' mental schemata of habitats and the habitatspecies coupling using the specific example of mutton snapper as a prototype. The relationship between fishers' ecological knowledge and their fishing success has been probed, finding that human factors such as knowledge and skill may play as much of a role in fishing success as material or technological factors (Bjarnason and Thorlindsson 1993), and that LTK may correlate positively with success, where success is understood as a fisher's ability to manage unpredictability in a complex, changing environment (García-Quijano 2009).

A second, growing body of literature discusses the role of LTK in national and international policy (Agrawal 1995, Mauro and Hardison 2000, Berkes et al. 2001b, Agrawal 2002, Memon et al. 2003, Ellis 2005). For example, Satria (2007) analyses why traditional fishing practices ceased and then were reinstated in Indonesia. Power and Mercer (2003) describe the role of fishers' knowledge in the implementation of the Oceans Act in Canada, while Shepert (2008) describes the relationship between LTK and the legal framework for finfish aquaculture in British Columbia. More broadly, Zurba (2009) examines how local knowledge may be excluded from governance systems due to existing policies, drawing on data from Great Barrier Reef Marine Park. Finally, Jones et al. (2010) note the important role of LTK in marine spatial planning, which from the Haida First Nation's perspective, is foundational to successful comanagement with Canada's Department of Fisheries and Oceans.

A third body of literature critically reflects on methods (Neis et al. 1999, Neis and Felt 2000, Berkes et al. 2001a, Vayda et al. 2006, Watson and Huntington 2008) and ethics in LTK research (Wenzel 1999, Maurstad 2002, Silver and Campbell 2005). These studies caution against simple, extractive approaches and show how deeper-level ethnographic, participatory, and iterative methods can lead to more ethical, respectful, and constructive engagements with LTK bearers and indigenous communities. The benefits of a deep ethnographic approach, often involving years of research, are evident in a handful of classic marine LTK monographs (e.g., Malinowski 1922, Nelson 1969, Johannes 1981).

Fourth, some work has sought to compare LTK and data gathered by Western scientific methods. For example, Silvano and Valbo-Jorgensen (2008) compare Brazilian fishermen's knowledge with published studies, finding cases of both agreement and disagreement, as do Batista and Lima (2010) in a similar examination of knowledge of jaraquis. Silvano and Valbo-Jorgensen argue that divergent results should prompt new studies rather than lead to the assumption that one knowledge system has the right answer. Daw et al. (2011) compares fishers' reports of catch rates with official landings data and underwater visual census (UVC) in the Seychelles, finding that each data source gave different perceptions of trends in the biomass of fish and catches over the study period. Other such studies have compared seasonal abundance patterns (Manajarréz-Martínez et al. 2010) and seabird chick emergence and size (Moller at al. 2009a). Aporta and Macdonald (2011) contrast scientific and Inuit approaches to sea ice, focusing on the difficulty of documenting the complex interplay of Inuit knowledge and practices outside the context of sea ice travel.

In other cases, rather than comparing knowledge from both LTK and science, work on climate change in the Arctic in particular has sought to improve our understanding of climate change by examining both scientific and Inuit perspectives (for example, Laidler 2006). Finally, a few studies have probed the relationship between scientific and indigenous epistemologies in the context of collaborative management projects (Fienup-Riordan 1999, Zavaleta 1999, Norton 2002, Gearheard et al. 2006, Leduc 2007, Murray et al. 2008). Dale and Armitage (2011) posit a set of five interrelated dimensions -knowledge gathering, sharing, integration, interpretation, and application-requisite for successful knowledge coproduction and adaptive capacity building in Arctic marine mammal comanagement (see also Armitage 2005, Armitage et al. 2007). On a similar theme, Pulsifer et al. (2011) discuss how a sea ice data management system could be structured so as to create a process that includes data based on indigenous knowledge systems linked to data collected in the Western scientific tradition. 
This summary of work examining marine LTK as a knowledge system illustrates how the literature focuses not only on knowledge and on the practices themselves, but may also consider processes by which LTK is transmitted within a community or into broader society, and in light of changes, such as technological innovation, that communities face. One potential gap in this literature is an exploration of what conditions are necessary for the continued creation and maintenance of LTK. If LTK is a living, dynamic body of knowledge then, like science, it requires application and refinement in practice in order to persist. Dale and Armitage (2011:446) emphasize that "application is not an end-point in a knowledge co-production process, but rather involves the translation of evolving knowledge into specific management decisions and the development, modification and evaluation of the plans and programs it shapes." Evolving knowledge is also a theme for Aporta and Higgs (2005:738), who analyze how GPS technology affects traditional way-finding, and note that 'despite the well-known Inuit ability to adapt to new technologies and new circumstances, GPS technology has the potential to deeply modify and cause disengagement from a well-established approach to the geographic surroundings and to the environment in general." Other work, such as that of Reyes-Garcia et al. (2007), which considers how market integration of Amazonian societies affects botanical LTK, may be useful in revealing what critical constraints shape the contemporary development and maintenance of marine LTK. These studies suggest that while LTK does not simply erode or ossify in the wake of social, technical, and environmental change, its content, resilience, and adaptive development are not guaranteed and depend on a range of interrelated factors.

\section{MARINE LTK RESEARCH TO DATE: AIMS, SUBJECT MATTER, AND POTENTIAL}

This part reviews the aims and focus of marine LTK research to date, highlighting the roles that LTK plays, and could potentially play, in the governance of marine social-ecological systems. We proceed first by defining key terms and the review's scope.

\section{Definitions and scope of review}

A broad range of concepts, topics, and terms can be related to LTK, including indigenous knowledge (IK), indigenous skill, folk knowledge, informal knowledge, ethnobiology, ethnoscience, and ethnoichthyology. As noted above, LTK is best understood as integrated and situated knowledge rather than as merely an assemblage of facts; an oft-cited definition of traditional ecological knowledge (TEK) is that it is "a cumulative body of knowledge, practice, and belief, evolving by adaptive processes and handed down through generations by cultural transmission, about the relationship of living beings (including humans) with one another and with their environment" (Berkes et al. 2000:1252). LTK and TEK are used synonymously here, though LTK is perhaps a broader term because it may include knowledge that is, strictly speaking, not ecological (Berkes 2008). Marine LTK may thus embrace subjects ranging from indigenous knowledge of salmon spawning grounds to the multiple Inuit terms for sea ice, commercial fishermen's knowledge of bait-to-catch ratios, and navigators' knowledge of currents and tides. The term "marine" is similarly broad, and for our purposes includes LTK relating to the zone between the deep sea and coastal habitats.

Our study was carried out by surveying the scholarly literature via electronic databases and library catalogue searches for relevant sources. The review effort attempted to be as comprehensive as possible, but some subject areas were excluded. Inland waters are generally excluded except where they relate to animals that travel inland from the ocean to spawn or to seabirds that inhabit delta regions. Wetlands are also excluded. Moreover, while there is also a burgeoning field of literature dedicated to indigenous knowledge and climate change, this review is limited to studies that are directly concerned with the components of the marine environment, such as sea ice. In addition, the review excludes most work related to prehistory, as well as the medicinal uses of marine resources (cf. Demunshi and Chugh 2010). The review includes studies that describe LTK and those that analyze specific practices, as long as the latter draw links between the practices and ecological knowledge.

The study reviewed over 240 scholarly articles and books. Geographically, of the articles and books that focus on a particular location, $42 \%$ of the research is centered in North America (with studies in Arctic Canada and Alaska accounting for 54\% of those North American articles), 22\% in Oceania, and $12 \%$ in Asia, with each of Africa, Europe, South America, and Central America and the Caribbean) accounting for 2 to $8 \%$ of the articles. The predominance of articles from North America reflects a similar finding by Brook and McLachlan (2008) in a broad review of the use of LEK in scholarly research. This dominance can be attributed to the rapid development of these studies among northern indigenous peoples in conjunction with management, conservation, and development initiatives in North America (cf. Cruikshank 2001, Hunn et al. 2003, Turner and Berkes 2006).

\section{Aims of marine LTK research}

Given the calls for greater collaboration between scientists and local knowledge holders, we first examine the aims of academic research relating to marine LTK. Broadly put, marine LTK studies can be divided into "documentation" type studies that add to existing knowledge for various uses, and more instrumental studies that explicitly seek to improve marine resource management.

\section{Documentation and research design}

Documentation studies are those that describe and interpret LTK within a cultural or cross-cultural context (see, Table 1). For example, within anthropology there is a long history of 
Table 1. Species-specific studies.

\begin{tabular}{|c|c|c|}
\hline LTK collected & Species & Source \\
\hline \multirow{8}{*}{$\begin{array}{l}\text { Current abundance and spatial } \\
\text { distribution of species }\end{array}$} & Beluga whales & Carter and Nielsen 2011 \\
\hline & Bumphead parrotfish & Aswani and Hamilton 2004, Dulvy and Polunin 2004 \\
\hline & Bowhead whales & Noongwook et al. 2007 \\
\hline & Goliath grouper & Cavaleri Gerhardinger et al. 2009b \\
\hline & Ivory gull & Mallory et al. 2003 \\
\hline & Oysters & Hill et al. 2010 \\
\hline & Polar bears & Dowsley and Wenzel 2008 \\
\hline & $\begin{array}{l}\text { Spatial variation in emergence of sooty shearwater } \\
\text { chick }\end{array}$ & Moller et al. 2009a \\
\hline \multirow[t]{6}{*}{ Migratory or seasonal movements } & Beluga whale & Huntingdon et al. 1999, Mymrin et al. 1999 \\
\hline & Bowhead whale & Noongwook et al. 2007 \\
\hline & Brazilian coastal fish & Silvano et al. 2006 \\
\hline & Cod & Murray et al. 2008 \\
\hline & Jaraquis & Batista and Lima 2010 \\
\hline & Pomatomus saltatrix & Silvano and Begossi 2005 \\
\hline \multirow[t]{2}{*}{ Sightings of species } & Dugongs & Rajamani and Marsh 2010 \\
\hline & Sharks & Rasalato et al. 2010 \\
\hline Stranding incidents & Dugongs & Rajamani and Marsh 2010 \\
\hline Health of species & Condition of polar bears & Dowsley and Wenzel 2008 \\
\hline Size of species & Patterns in size of Puffinus griseus chicks & Moller et al. 2009a \\
\hline \multirow[t]{2}{*}{ Life history } & Goliath grouper & Cavaleri Gerhardinger et al. 2006 \\
\hline & Jaraquis (size of sexual maturity, growth, mortality) & Batista and Lima 2010 \\
\hline Stock structure & Cod & Gosse et al. 2003, Murray et al. 2008 \\
\hline Key habitats & Gadoid fishes & Bergmann et al. 2004 \\
\hline \multirow[t]{3}{*}{ Spawning and nursery areas } & Cod & Ames 2007 \\
\hline & Goliath grouper & Aguilar-Perera et al. 2009 \\
\hline & Multiple fish species & Knutsen et al. 2010 \\
\hline \multirow[t]{8}{*}{ Past abundance } & Beluga whales & Carter and Nielsen 2011 \\
\hline & Chinese bahaba & Sadovy and Cheung 2003 \\
\hline & Cod stocks & Rosenberg et al. 2005 \\
\hline & Frigate tuna & Venkatachalam et al. 2010 \\
\hline & Goliath grouper & Aguilar-Perera et al. 2009 \\
\hline & Herring & Jones 2007, Thornton et al. 2010 \\
\hline & Lobster (Jasus frontalis) & Eddy et al. 2010 \\
\hline & Multiple finfish species (local extinction) & Lavides et al. 2009 \\
\hline \multirow[t]{3}{*}{ Behavior } & Carangidae fish aggregation & Hamilton and Walter 1999 \\
\hline & Polar bears & Keith et al. 2005, Lemelin et al. 2010 \\
\hline & Dugongs & Johannes and MacFarlane 1991 \\
\hline \multirow[t]{9}{*}{ Reproduction-related behavior } & Breeding of geese in relation to storm surges & Fienup-Riordan 1999 \\
\hline & Calving in beluga whales & Huntingdon et al. 1999, Mymrin et al. 1999 \\
\hline & Nesting-site fidelity in sea turtles & Johannes and Neis 2007 \\
\hline & Parental care in jaraquis & Batista and Lima 2010 \\
\hline & Reproduction in various coastal fish & Silvano et al. 2006 \\
\hline & Reproduction in Pomatomus saltatrix & Silvano and Begossi 2005 \\
\hline & Spawning of longfin emperor & Hamilton 2005 \\
\hline & Spawning behavior of various reef fishes & Boomhower et al. 2007 \\
\hline & Lunar cycles and fish reproduction & Johannes et al. 1981 \\
\hline \multirow[t]{4}{*}{ Feeding behavior } & Beluga whales & Huntingdon et al. 1999, Mymrin et al. 1999 \\
\hline & Jaraquis & Batista and Lima 2010 \\
\hline & Polar bears & Lemelin et al. 2010 \\
\hline & Pomatomus saltatrix & Silvano and Begossi 2005 \\
\hline \multirow[t]{3}{*}{ Effect of physical environment } & Effects of lunar periodicity on fish & Aswani and Hamilton 2004 \\
\hline & Reactions of eider to shifting ice pack & Gilchrist and Robertson 2000 \\
\hline & Effects of climate variability on Arctic char & Knopp 2010 \\
\hline \multirow{3}{*}{$\begin{array}{l}\text { Human-animal interactions and } \\
\text { effects }\end{array}$} & Polar bears & Keith et al. 2005, Lemelin et al. 2010 \\
\hline & Reactions of seals to fishing nets & Moore 2003 \\
\hline & Reactions of tuna to fishing devices & Moreno et al. 2007b \\
\hline
\end{tabular}


documenting indigenous environmental knowledge and its uses within ethnoscience, ethnobiology, and ethnoecology studies. Alternatively, LTK has contributed to structuring and refining the focus of scientific research projects (Hamilton and Walter 1999, Bart 2006, Moreno et al. 2007b). For example, Bart (2006) used information from salt hay farmers about an invasive reed in order to design manipulative experiments that were able to shed light on the causal mechanisms underlying the observations of locals. He argues that "local accounts may provide rich narrative histories that can both refine research questions and suggest multiple plausible scenarios" (Bart 2006:546). Marine LTK can also provide the groundwork for research projects in data-spare situations. For example, LTK has provided initial assessments of both Mayan (Arce-Ibarra and Charles 2008) and Guinean fisheries (Poizat and Baran 1997). In addition, LTK may yield information about the historical structure of and changes in marine flora and fauna, ecosystems, and seascapes (Sadovy and Cheung 2003, SaenzArroyo et al. 2005a, Roberts 2007, Thornton et al. 2010, Shackeroff et al. 2011).

\section{Improving resource management}

The bulk of recent LTK research has been conducted with resource management in mind. Table 2 highlights three broad categories of studies. These categories include improving management through increased knowledge, improving or assessing management techniques, and informing conservation strategies.

The studies set out in Table 2 give some sense of the breadth of ways in which LTK can contribute to marine resource management. Moreover, specific studies within each of these categories illustrate the unique role that LTK can play in management and conservation. First, in relation to improving management simply through increasing the knowledge base about a given species or habitat, such an observation is most apparent in relation to studies that examine LTK of environmental change. In many cases, scientific measures are either too narrow, shallow, or broad to be meaningful in the context of community adaptation at the landscape scale. LTK anchored in particular locales over generations, in contrast, systematically records and contextualizes observations, which can help ground truth environmental events, impacts, and projections that may be captured only by scientific instruments or models at a very broad scale, if at all. Ames (2007:154) argues that the preoccupation of contemporary fisheries science with simplified models "has left it without the historical parameters needed to interpret fine-scale changes in stock distribution, behavior, or migration patterns over time. Consequently, management has lacked the ability to detect or interpret these changes ..." Using LTK can thus be especially meaningful in recognizing and interpreting changes in habitat, species abundance and distribution, sea-ice qualities, and the like (Knopp 2010, Krupnik et al. 2010, Lauer and Aswani 2010).
Second, LTK has brought to light potentially useful traditional practices or institutions that could be incorporated into "contemporary" resource management. For example, it has been argued that the values, knowledge, and stewardship practices of First Nations peoples could be fruitfully integrated into the management and restoration of watersheds and coastal habitats (e.g., Berkes 1977, Jones and Williams-Davidson 2000, Thornton et al. 2009, Thornton and Kitka 2010, Thornton et al. 2010, Thornton 2012). At the same time, some works caution against a hasty borrowing of traditional practices for management (e.g., Palmer 1994:238), especially where population, habitat, or use conditions have changed appreciably. LTK's very inclusion in management processes may change the broader social context to foster community empowerment in participatory management, such as in seaurchin harvesting in St. Lucia (Warner 1997). This valorization, reflecting LTK's continuing legitimacy and development, may in turn improve the resilience of the local knowledge and practices by encouraging young people to retain it "as a matter of personal experience" (Johannes 1981:149).

Studies highlighting LTK's role in management conflicts shows that collaboration between LTK holders and scientists holds potential for improving stewardship. For example, Dowsley and Wenzel (2008:184) explore varying perceptions of polar bear abundance in Nunavut in the context of a comanagement arrangement, finding that disagreements over polar bear population numbers may be the result of either or both "incomplete data collection and synthesis among Inuit observers, or of scientific data collection that is too narrowly confined in geographic area." They also note the possibility that LTK bearers have not yet perceived declines in bear conditions or population size, and suggest that improved collaboration between locals and scientists in interpreting large-scale scientific studies in relation to local observations might lead to broader consensus about the status and management of polar bears (Dowsley and Wenzel 2008:186). Huntington et al. (2004) emphasize similar spatial complementarity in studying the migration of beluga whales.

Third, in relation to conservation and marine spatial planning, numerous studies underscore the useful role of LTK. Drew (2005) argues that TEK can strengthen conservation programs through improved knowledge of the specific location and relevant environmental linkages, and through the improved local capacity and power sharing that comes with including knowledge holders as equal partners in research programs. LTK can be especially valuable in planning and assessing Marine Protected Areas (MPAs). For example, Ban et al. (2009) developed a framework for integrating the preferences and concerns of First Nations peoples into the site selection of potential MPAs. A recent review of MPAs suggests there is a long way to go, however, because "potentially existing 
Table 2. Management-focused marine LTK studies: examples from the literature.

\begin{tabular}{|c|c|c|}
\hline Broad aim & LTK-management focus & Examples \\
\hline \multirow{9}{*}{$\begin{array}{l}\text { Increase knowledge } \\
\text { base to improve } \\
\text { management }\end{array}$} & Species or habitat & Silvano et al. 2006, Hill et al. 2010, Lemelin et al. 2010, Rasalato et al. 2010 \\
\hline & Stock numbers & Neis 1992, Foale 1998, Saenz-Arroyo 2005a, Jones 2007 \\
\hline & Sightings & Rajamani and Marsh 2010 \\
\hline & Seasonal patterns & Manajarréz-Martínez et al. 2010 \\
\hline & Stock structure & Gosse et al. 2003, Nielsen 2009 \\
\hline & Hunting incidence/incidental catch & Rajamani and Marsh 2010 \\
\hline & Environmental change & Lauer and Aswani 2010, Knopp 2010 \\
\hline & "Shifting baselines" & $\begin{array}{l}\text { Saenz-Arroyo et al. 2005b, Eddy et al. 2010, Thornton et al. 2010, } \\
\text { Venkatachalam et al. } 2010\end{array}$ \\
\hline & $\begin{array}{l}\text { Identify commonalities between LTK and } \\
\text { commercial fishers knowledge }\end{array}$ & Batista and Lima 2010 \\
\hline \multirow{12}{*}{$\begin{array}{l}\text { Assess, improve, and } \\
\text { or/develop } \\
\text { management } \\
\text { techniques }\end{array}$} & $\begin{array}{l}\text { Examine seabird egg harvesting strategies in } \\
\text { relation to population ecology }\end{array}$ & Hunn et al. 2003 \\
\hline & $\begin{array}{l}\text { Bring to light potentially useful traditional } \\
\text { practices }\end{array}$ & $\begin{array}{l}\text { Berkes 1977, Baines and Hviding 1993, McClanahan et al. 1997, Johannes } \\
\text { 1998, Jones and Williams-Davidson 2000, Johannes 2002, Mathooko 2005, } \\
\text { Linkous Brown 2006, Menzies and Butler 2007, Ashaletha and Immanuel } \\
\text { 2008, Heaslip 2008, Thornton 2008, Rathakrishnan et al. 2009, Satria and } \\
\text { Adhuri 2010, Thornton and Kitka 2010 }\end{array}$ \\
\hline & $\begin{array}{l}\text { Improve management practices in commercial } \\
\text { fisheries }\end{array}$ & $\begin{array}{l}\text { Moore 2003, Price and Rulifson 2004, Harnish and Willison 2009, Moreno et } \\
\text { al. 2007a, Szuster and Albasri } 2010\end{array}$ \\
\hline & Resolve management disputes & Davis et al. 2004, Dowsley and Wenzel 2008 \\
\hline & Assess parametric fisheries management & Acheson and Wilson 1996 \\
\hline & Protocols for incorporating GIS and LTK & Calamia 1999, Close and Hall 2006, St. Martin and Hall-Arber 2008 \\
\hline & GIS mapping of mapping local fishing areas & Anuchiracheeva et al. 2003 \\
\hline & GIS mapping of spawning and nursery areas & Knutsen et al. 2010, Thornton et al. 2010 \\
\hline & Classification of remote sensing imagery & Lauer and Aswani 2008 \\
\hline & Develop expert system models & Mackinson 2001, Grant and Berkes 2007 \\
\hline & Develop parametric indicators & Wilson et al. 2006 \\
\hline & Inform marine spatial planning & Cinner et al. 2010 \\
\hline \multirow{12}{*}{$\begin{array}{l}\text { Develop and } \\
\text { inform conservation } \\
\text { strategies }\end{array}$} & Identify essential habitats & Bergmann et al. 2004 \\
\hline & Bringing together fisher and scientist knowledge & Akimichi 2001 \\
\hline & Construction of artificial reefs & Kurien 2001 \\
\hline & Assess effectiveness of conservation zone & Baird and Flaherty 2005 \\
\hline & Assess conservation status of species & Dulvy and Polunin 2004 \\
\hline & $\begin{array}{l}\text { Determine local extinction vulnerability of species } \\
\text { in IUCN hotspots }\end{array}$ & Castellanos-Galindo et al. 2011 \\
\hline & $\begin{array}{l}\text { Identify potential environmental and human-related } \\
\text { factors impacting beluga whales }\end{array}$ & Carter and Nielsen 2011 \\
\hline & Inventory the disappearance of certain fish & Lavides et al. 2010 \\
\hline & $\begin{array}{l}\text { Improve conservation through targeted data } \\
\text { collection }\end{array}$ & $\begin{array}{l}\text { Cavaleri Gerhardinger et al. 2006, Richmond et al. 2007, Cavaleri } \\
\text { Gerhardinger et al. 2009b }\end{array}$ \\
\hline & Study fisher perception of conservation efforts & Rosa et al. 2005 \\
\hline & Inform mangrove restoration & Biswas et al. 2009 \\
\hline & Creation and evaluation of marine protected areas & $\begin{array}{l}\text { Aswani and Hamilton 2004, Scholz et al. 2004, Aguilar-Perera et al. 2006, } \\
\text { Aswani and Lauer 2006, Mallory et al. 2006, Aswani et al. 2007, Mow et al. } \\
\text { 2007, Aswani and Vaccaro 2008, Ban et al. 2008, Ban et al. 2009, Cavaleri } \\
\text { Gerhardinger et al. 2009a, Espinoza-Tenorio et al. } 2010\end{array}$ \\
\hline
\end{tabular}

ecological knowledge of local communities is seldom acknowledged when designing MPAs" (Ferse et al. 2010:26). Indeed, in the context of a national park in southern Brazil, Almudi and Coswig Kalikoski (2010:225) found that a topdown MPA model “disregarded the fisherfolk's cultural practices and particular knowledge, thereby violating their rights as traditional people." Such violations tend to further undermine the integrity and resilience of LTK and livelihood systems.

Substantive focus of LTK research

A broad review of the literature reveals that LTK has been collected about many facets of marine environments, though species-specific studies are particularly prominent. Table 1 details these findings. 
Table 3. How the substantive focus of marine LTK studies has broadened: examples from the literature.

\begin{tabular}{|c|c|c|}
\hline Category & Study focus & Examples \\
\hline \multirow[t]{5}{*}{ Ecology } & Marine habitats, spawning and nursery areas & Knutsen et al. 2010, Thornton et al. 2010 \\
\hline & Historical ecology of coral reef guilds & Shackeroff et al. 2011 \\
\hline & Mangroves and lagoons & $\begin{array}{l}\text { Johannes 1978, Johannes 1981, Kovacs 2000, Hernandez Cornejo } \\
\text { et al. 2005, Aswani and Lauer 2006, Walters et al. } 2008\end{array}$ \\
\hline & Seagrass environments & $\begin{array}{l}\text { Lauer and Aswani 2010, Turner and Clifton 2006, Wyllie- } \\
\text { Echeverria et al. } 2002\end{array}$ \\
\hline & Marine/coastal habitats and tsunami impacts & Venkatachalam et al. 2010 \\
\hline \multirow{22}{*}{$\begin{array}{l}\text { Physical environment and } \\
\text { cultural adaptation }\end{array}$} & Tidal cycles and wind patterns & Tobisson et al. 1998, Nirmale et al. 2004a \\
\hline & Lunar cycles & Cordell 1974, Nirmale et al. 2004a \\
\hline & Effect of water color on catch & Nirmale et al. 2004a \\
\hline & Weather and climate & Lefale 2010 \\
\hline & Indicators of cyclone intensity & Nirmale et al. 2004b, 2007 \\
\hline & Seabed morphology & Tobisson et al. 1998 \\
\hline & Finding fishing spots based on physical environment & Forman 1967, Schafer and Reis 2008 \\
\hline & Response to potentially tsunami-forming earthquakes & McAdoo et al. 2009 \\
\hline & $\begin{array}{l}\text { Interpreting satellite images and aerial photos using } \\
\text { LTK }\end{array}$ & Aswani and Lauer 2006 \\
\hline & Tropical coastal habitat connectivity & Garcia-Quijano 2007 \\
\hline & Currents and island wakes & Johannes 1981 \\
\hline & $\begin{array}{l}\text { Sea ice (freeze/thaw processes, influence of winds and } \\
\text { currents) }\end{array}$ & $\begin{array}{l}\text { Nelson 1969, Dowsley and Wenzel 2008, Laidler and Elee 2008, } \\
\text { Laidler and Ikummaq 2008, Aporta and Macdonald 2011, Inuksuk } \\
2011\end{array}$ \\
\hline & Adaptation to sea ice environment & Riewe 1991, George et al. 2004 \\
\hline & Incorporation of sea ice LTK and satellite imagery & Laidler et al. 2011 \\
\hline & Glaciers & Cruikshank 2001, 2005 \\
\hline & Navigation (general) & Paine 1957, Gladwin 1970, Finney 1976, and Feinberg 1988 \\
\hline & Navigation (landmarks) & Forman 1967, 1970, Igarashi 1984, Ammarell 1995 \\
\hline & Navigation (stars, swells) & Ammarell 1995, Feinberg 1995 \\
\hline & Navigation in the Arctic & Aporta 2002, 2004, 2009 \\
\hline & Using GPS to map trails & Aporta 2003 \\
\hline & Collaborative mapping & Gearheard et al. 2011 \\
\hline & Weather/ocean/climate conditions & Alvarez and Vodden 2009 \\
\hline \multirow{8}{*}{$\begin{array}{l}\text { Assessing environmental } \\
\text { change }\end{array}$} & Mangrove forests (e.g., disturbance, extent) & Kovacs 2000, Hernandez Cornejo et al. 2005 \\
\hline & $\begin{array}{l}\text { Geographic distribution, seasonality and severity of } \\
\text { algal blooms }\end{array}$ & Schlacher et al. 2010 \\
\hline & $\begin{array}{l}\text { Long-term ecological change in seagrass meadows and } \\
\text { causal factors }\end{array}$ & Lauer and Aswani 2010 \\
\hline & $\begin{array}{l}\text { Nearshore macrobenthos affected by local sewage } \\
\text { disposal }\end{array}$ & Jewett et al. 2009 \\
\hline & Climate variability and Arctic & Knopp 2010, Barber et al. 2010 \\
\hline & Changes in sea ice & Gearheard et al. 2006 \\
\hline & Relationship between sea ice and climate change & Laidler 2006 \\
\hline & Climate-walrus-human relationships & Krupnik and Carleton Ray 2007, Metcalf and Robards 2008 \\
\hline \multirow[t]{8}{*}{$\begin{array}{l}\text { Language and marine } \\
\text { cognition }\end{array}$} & Names for fish & $\begin{array}{l}\text { Akimichi 1978, Akimichi 1986, Ankei 1989, Ambali et al. 2001, } \\
\text { Anderson } 2007\end{array}$ \\
\hline & Marine invertebrates & Sloan and Barthier 2009 \\
\hline & Names for hydrological features & Burenhult 2008 \\
\hline & Landscape and seascape terms & $\begin{array}{l}\text { Cablitz 2008, Levinson 2008, O'Conner and Kroefges 2008, Senft } \\
\text { 2008, Thornton } 2011\end{array}$ \\
\hline & Coastal proverbs & Kurien 1998 \\
\hline & Terms for sea ice conditions & $\begin{array}{l}\text { Norton 2002, Laidler and Elee 2008, Laidler and Ikummaq 2008, } \\
\text { Heyes 2011, Krupnik } 2011\end{array}$ \\
\hline & Ancestral sayings and a coastal wetland plant & Wehi 2009 \\
\hline & Terms for tidal current patterns & Johannes et al. 1981 \\
\hline Resource management & $\begin{array}{l}\text { Management practices in small-scale subsistence or } \\
\text { commercial fisheries (artisanal fisheries) }\end{array}$ & $\begin{array}{l}\text { Morrill 1967, Johannes 1978, Johannes 1981, Klee 1980, Swezey } \\
\text { and Heizer 1984, Amos 1993, Johannes and Yeeting 2000, Blount } \\
\text { 2005, Hickey 2007, Thornton 2008, Mangahas 2010, Nguyen and } \\
\text { Ruddle 2010, Satria and Adhuri 2010, Coulthard 2011 }\end{array}$ \\
\hline
\end{tabular}


Basic fisheries assessments

Fish harvesting techniques and technologies (artisanal)

Assessing bait to catch ratios (commercial)

Bycatch assemblages

Changing uses of bycatch

Comparative study of fishing tuna

Spatial distribution of scallops (commercial)

Spatial distribution of lobster

Harvesting methods for seaweeds

Assessing effectiveness of conservation measures

Village-managed fish conservation zones
Arce-Ibarra and Charles 2008

Akimichi 1986, Hviding 1996, Anuchiracheeva et al. 2003 ,

Linkous Brown 2006, Nirmale et al. 2004a, Nirmale et al. 2004b, Langdon 2006, Nirmale 2007, Nsiku 2007, McClanahan and

Cinner 2008, Manna et al. 2009, Rathakrishnan et al. 2009

Harnish and Willison 2009

Hill et al. 2010

Lobo et al. 2010

Moreno et al. $2007 \mathrm{a}$

Wroblewski et al. 2009

Acheson 1988

Turner and Clifton 2006

McClanahan et al. 1997

Baird and Flaherty 2005
Not surprisingly, LTK collected in these studies is focused at the human scale of experience. For example, animal-related LTK focuses especially on species that are hunted, while that which deals with physical geography generally relates to navigation and safety. This emphasis supports the view that fishers' ecological knowledge is primarily, though not exclusively, utilitarian (McGoodwin 2001). Indeed, Foale (1998:200) remarks that most LTK "possessed by subsistence, artisanal and commercial fishers is focused on how to locate individuals of a target species in space and time, and, once located, how to capture them." Baines (1992:100) adds that on a Pacific island, fishers' knowledge is instrumental, or "primarily behavior oriented, focusing on the information required to find and capture." Correlatively, "empirical gaps" (Foale 2006a) in LTK concern parts of the life cycle that are comparatively unknown to fishers because they are beyond the scope of their experience or perception. Thus local observations and traditional knowledge are generally not very useful at chemical, biochemical, or cellular levels (Berkes et al. 2007). On the other hand, the phenotypic manifestations of chemical changes within an animal may be readily perceived by LTK holders.

Table 3 summarizes marine LTK studies relating to ecology, the physical environment, assessments of environmental change, language, and resource management. The table illustrates how the substantive focus of modern LTK studies has broadened beyond knowledge of species to include marine ecological and physical processes. Knowledge of marine ecology is often built up and maintained in the context of specific subsistence practices, such as hunting and fishing, which are conditioned by broader ecosystem dynamics (Johannes and MacFarlane 1991). For example, following a 2007 tsunami in the Solomon Islands, McAdoo et al. (2009:81) found that indigenous knowledge can be "an effective tsunami mitigation tool when the right combination of education and physiography come together". Many authors (Wohlforth 2005, Laidler and Elee 2008, Riewe and Oakes 2006, Henshaw 2009, Gearheard et al. 2011, Pearce et al. 2011, ) suggest that LTK can be used not only to understand the physical and socio- cultural risks, vulnerabilities, and other impacts of climate change in the Arctic but also as a source of resilience and adaptive capacity in response to these changes.

Moreover, classical ethnoscience studies carried out by linguists and ecological anthropologists (cf. Conklin 1957) have recognized the importance of language and nomenclature in reflecting the LTK of environments. Indeed, names for marine species, habitats, and the like can be an important first step in integrating LTK with scientific knowledge (Sloan and Barthier 2009). The potential link between the richness of terminology and knowledge of geological features and processes has also been highlighted in recent studies (Terry and Etienne 2011). There is scope to further explore such relationships between language, culture, and marine ecology and biocultural diversity.

In parallel with the studies described above, which aim to improve management techniques, another body of research embraces the diversity of community resource management practices. For example, Klee (1980; see also Johannes 1981) describes taboos and bans in lagoon tenure systems in the South Pacific Islands, as well as the figure of the "Master Fishermen" who acted as an island's authority on fishing lore and practice. Thornton $(2008,2012)$ describes a similar "Master of the Stream" figure for important Tlingit salmon watersheds in southeast Alaska, and Swezey and Heizer (1984) link the "first salmon" ritual of multiple aboriginal communities in California to conservation practice. Knowledge of this diversity can improve regulatory regimes when these rules do not conflict with sustainable local practices; McClanahan and Cinner 2008), for example, examined the fishing gear used by a community in Papua New Guinea, and suggest that LTK in tandem with scientific monitoring could be used to establish an adaptive management framework for gear restrictions.

\section{AN EMERGING FOCUS ON COLLABORATIVE RESEARCH AND MANAGEMENT}

As noted above, collaboration and the coproduction of knowledge between LTK communities, scientists, and 
Table 4. Collaborative projects that bridge LTK and science: examples from the literature.

\begin{tabular}{lll}
\hline \hline Examples & Focus & Methods \\
\hline Baines 1992 & Various subjects, focusing on fish and fishing & Researchers resident in community, reciprocal training \\
Carmack and Macdonald 2008 & Water and ice-related phenomena (Arctic Canada) & Dialogue with elder \\
Fernandez-Giminez et al. 2006 & Beluga whales (Alaska) & Comanagement committee \\
Fienup-Riordan 1999 & Geese (Alaska) & Interviews \\
Gearheard et al. 2006 & Sea ice (Alaska/Canada) & Knowledge exchange with field trips \\
Hall et al. 2009 & Oyster fishery (New Zealand) & Participatory monitoring \\
Krupnik 2002 & Ice and weather (Alaska) & Workshop and locally led documentation project \\
Moller et al. 2009b & Seabird harvest (New Zealand) & Long-term research partnership \\
Norton 2002 & Sea ice (Alaska) & Symposium \\
Obura et al. 2002 & Local fish monitoring (Tanzania) & Community engagement in research \\
Tremblay et al. 2008 & Local climate (Arctic Canada) & Community-based monitoring \\
\hline
\end{tabular}

resource managers on research and management projects is a potentially constructive pathway to bridge science and LTK. The growing literature on collaborative projects is instructive in providing guidelines for how to approach this bridging in ways that maintain the integrity of knowledge systems and enhance exchange between them, while at the same time improving adaptive management. This section examines eleven examples of collaborative projects. Table 4 lists the main studies examined, and their focus and methods. The table makes it clear that the majority of these examples come from the North American Arctic, where it would appear there is the most collaborative research activity. The following analysis therefore bears in mind this context, although it is arguable that a number of the considerations discussed will be applicable elsewhere.

How have collaborative projects managed the relationship between LTK and modern science? The differences between LTK and modern science are often significant (Cruikshank 2005) and underpinned by foundational differences in cosmology and worldview, but at the same time can be overdrawn (Agrawal 1995). As Krupnik (2002:185) suggests, "it is not a different nature but rather a different focus of scientific and 'local' knowledge, that commonly keeps these two types of expertise looking in different directions." An appreciation of where LTK and science have their relative expertise is thus important, as is the relative status of that expertise (Laidler 2006) and mutual respect (Moller et al. $2009 b$ ). In cases where the focus or scale of inquiry may be the same, collaborative research may take science and LTK as equals. Carmack and Macdonald (2008:25) term this approach "coscience" where "natural phenomena are examined through both indigenous and Western methods; each approach is assumed valid within its own set of rules and neither replaces the other." They argue further that "the practical and emergent outcome of this approach is that joint enquiry will focus on phenomena that are important to native peoples for their way of life and will bring Western scientists closer to a 'system science' level of understanding." Similarly, in a participatory mapping exercise, Hall et al. (2009:2059) aimed to create a "virtual space" in which LTK and science "can play equal roles relative to rekindling the broader goal of collaborative participation in management and planning." However, appreciative inquiry and participatory methods in themselves may not lead to the development of co-equal knowledge and management systems (Nadasdy 2003).

Fernandez-Giminez et al. (2006) delineate signs of successful integration of LTK and science. In examining the Alaska Beluga Whale Committee, they found that hunters began to communicate scientific knowledge, and even quite specific scientific studies, amongst each other, while scientists began to understand the broader cultural context and implications of their work. Moller et al. (2009b:234) report that Maori interest in research led to the formation of Maori research methodologies "where Maori remain in charge of research initiation, benefits, representation, legitimation and accountability." The process of getting to such an understanding may be a necessary first step toward developing co-equal knowledge and management systems, and can be fostered by setting collaboration milestones to achieve successful integration. Yet cases of native-led research and equitable partnerships between science and LTK, despite the promise of coscience, are still quite rare.

In terms of practical engagement, the importance of relationships and trust is emphasized in successful collaborative projects. Many scientists have noted the important role that ongoing relationships in a given community play in their work (Norton 2002, FernandezGiminez et al. 2006, Gearheard et al. 2006, Tremblay et al. 2008). Indeed, Moller et al. (2009b:219) note that of the attributes identified for successful comanagement by scientists and local resource managers, "trust and respect for each other were the most fundamental and time consuming to establish and demonstrate." Where such relationships did not initially exist, it was important for scientists to build trust and respect for themselves (Fienup-Riordan 1999). Norton 
(2002:131) describes how these relationships grew by "scientists learning to live and conduct fieldwork safely on the ice alongside whalers for two months each spring." In building these relationships, the creation of different opportunities in which communication can be fostered is important, through both formal and informal interactions (Baines 1992, Fernandez-Giminez et al. 2006, Gearheard et al. 2006). In particular, Gearheard et al. (2006:203) note that "opportunities for cultural exchange were an important aspect of the project that helped create trust and comfort in the research team." Obura et al. (2002) also argue that, particularly in the case of long-term monitoring, relationships are crucial, and that commitment from all actors involved is necessary. Even before any knowledge sharing can begin, and questions of how to bring together science and LTK can be raised, relationships based on trust and shared experience must be developed. Moller et al. (2004) note that studies which aim to combine scientific and traditional methods may be a fruitful context in which to build such relationships. Indeed, Turnbull (1997:551) affirms that there is a need to "enable disparate knowledge traditions to work together through the creation of a third space in which the social organization of trust can be negotiated."

In project design, this "third space" often springs from a shared interest in a vital subject. For example, both Norton (2002) and Tremblay et al. (2008) note that their focus on nearshore sea ice and its link to safety meant that their research was useful to the community, which is a compelling environmental change and management problem for study. Moller et al. (2009b) explain that concern for seabirds and their well-being meant that many birders saw long-term value in the research. In other cases, the desire to collaborate on formal documentation of LTK was motivated by the community's aim to safeguard the knowledge for future generations (Baines 1992, Krupnik 2002, Fernandez-Giminez et al. 2006, Hall et al. 2009).

The collaboration of LTK bearers in codirecting all phases of the research is consistently highlighted as an important element of successful projects. Research questions and protocol are best developed in collaboration with village elders (Fienup-Riordan 1999). In cases in which collaboration focuses on a group setting, it is crucial that the group be made up of locals and scientists (Fernandez-Giminez et al. 2006, Gearheard et al. 2006) and that the organizational structure be conducive to power sharing (Fernandez-Giminez et al. 2006). In cases in which collaboration emphasizes monitoring, an appropriate level of training is requisite (Obura et al. 2002). Ultimately, these factors contribute enormously to a constructive sense of cooperative ownership of the project (Fernandez-Giminez et al. 2006). These considerations are reflected in Pearce et al.'s (2009) review of collaborative climate change research in Arctic Canada, which also emphasizes the importance of having early and ongoing communication, involving communities in research design and development, and facilitating opportunities for employment and disseminating results. Correlatively, Gearheard and Shirley (2007) make a number of recommendations stemming from their analysis of natural sciences research in Nunavut, among them that trust-building can be fostered through early community consultation, regular research reports, and the use of local experience and resources.

However, as Obura et al. (2002:219) stress, project design must also help local communities build capacity for the collection, analysis, and dissemination of technical information so that their ability to participate in resource management is strengthened. Thus, funding for community participation and "the equitable sharing of resources to facilitate active participation is essential" (Moller et al. 2009b:229). Projects with such community benefits are more likely to garner community involvement and support that will enhance long-term relationships necessary for trust and capacity-building and adaptive learning about the benefits of LTK in relation to science.

Yet, collaborative research poses a number of challenges. The cases examined emphasize that perceptions of the role of science and the aims of the scientists may have an influence on how projects proceed, particularly at their inception. For example, Fienup-Riordan (1999) found that elders expressed deep resentment toward the nonlocal control that researchers and wildlife managers represented, while Fernandez-Giminez et al. (2006) note that hunters often perceived knowledge to be a tool of state control. Moller et al. (2009b) maintain that in order to succeed, research partnership projects require both a strong mandate from the community at large and active leadership from within the participating community. Project design therefore not only has to be cognizant of these attitudes but has to take positive steps to engage them by creating a new space for knowledge coproduction, colearning, and comanagement.

Logistically, the costs and complexity of creating such spaces can be high. Even setting up a simple knowledge exchange with field visits is expensive (Gearheard et al. 2006). Obura et al. (2002) discovered the difficulty of securing sufficient long-term funding for such things as monitoring. The pace of research is also likely to be slower than that done in the absence of a community of interest (Moller et al. 2009b). Other challenges to successful collaboration include: local employment trends and attitudes, revolving membership and leadership of community organizations, competing or concurrent local activities at the time of research, cultural barriers, poor historical research, community-researcher relations, the economic subtext of many community-research relationships, financial limitations, time constraints, and communicating results to stakeholders (Pearce 2009). These practical challenges can undermine the viability, equality, 
integrity, and resilience of coscience systems emerging in the third space.

Stable bridging institutions such as the Alaska Eskimo Whaling Commission remain the exception rather than the rule, and they require significant funding, logistical support, and community backing to carry out their mandates. Significantly, this institution was born in the early 1980s out of conflict surrounding a proposed international moratorium on whaling that could have ended Eskimo subsistence on foundational species like the bowhead. Instead, however, the Commission was created to improve the science at the local scale by incorporating LTK (which showed significantly more whales present than scientists had been able to count) and management (distribution of hunting quotas) in meaningful and substantive ways. This has been highly effective, as Huntington (1992:115) relates, because: (1) the whalers administer the allocation and scientific review regime; (2) the quotas reflect the real needs of communities for whales; (3) whaling is a major economic and communal activity with strong traditional protocols and support for sharing and cooperation; and (4) "the goals of the AEWC have always been clear, and the battle with an outside authority has helped the whalers form a cohesive group. By averting the threat to Eskimo culture, the AEWC proved its usefulness, earning the pride and respect of the whalers." In addition to this strong foundation and track record, the Commission is also comparatively well funded and high profile in its activities, reflecting its status and legitimacy across cultures.

\section{CONCLUSION: A COLLABORATIVE AGENDA FOR MARINE SCIENCE AND LTK}

Despite comprising more than $70 \%$ of the Earth's surface, marine environments remain among the least understood of ecosystems. Yet they are increasingly under threat from development, degradation, climate change, and other forces. A lack of historical-ecological depth in marine studies means that in many cases we do not realize what we have lost (Anderson 2007, Roberts 2007). Despite some classic studies, marine LTK research overall is relatively young and is evolving rapidly, and there is a critical need for more substantive, deep ethnographic and multiscale research on marine ecosystems, as our ocean-dominated planet continues to evolve and change.

The successes and challenges discussed provide some guidelines for how successful collaborative work may proceed to improve our understanding of marine systems and foster adaptive management as they change. A diversity of approaches is evident in the literature, including multilocal bridging organizations, such as the Alaska Beluga Whale Committee (Fernandez-Giminez et al. 2006). These comanagement organizations are made up of local and state actors that can "provide an arena for knowledge co-production, trust building, sense making, learning, vertical and horizontal collaboration and conflict resolution" (Berkes 2009a:1695).
Such institutions can create a forum in which local and scientific knowledge can be shared, produced, maintained, and used collaboratively. Dowsley (2009) advocates for a "community cluster approach" consisting of neighboring communities that share a spatially defined resource. She suggests that collaborative research would benefit from such a networked approach through increased information and monitoring that can lead to faster recognition of changes in the resource.

To keep the collaborative projects "moving forward" (Neis 2011), novel and hybrid approaches may be necessary to successfully represent LTK in the academy and beyond. Watson and Huntington (2008), for example, show how a traditional academic paper can be restructured to better represent different accounts of reality. Felt (2008) proposes that fisheries scientists in training should take part in a residency of a few months with local fishers, as such immersion through participant observation can help build trust and mutual appreciation and understanding. Workshops cosponsored with LTK holders may also provide "a practical and concrete basis upon which to build a shared understanding, or at least greater insight into the reasons behind divergent views" (Huntington et al. 2002:788). The Sitka Tribe of Alaska (a collaborator in numerous LTK studies) has, in the case of one key cultural species, gone beyond workshops to found the broad-based Sitka Sound Herring Research Planning Group to carry the collaborative agenda forward through regular communications, thereby building towards new research and management priorities that link local fishers' knowledge and practices to appropriate methods and scales of marine ecosystem governance. Like their Haida neighbors, the Sitka Tribe seeks to collaborate with scientists to improve understandings of critical, complex, and changing marine environments with the help of LTK. Unfortunately, the embrace of LTK by state management is still too limited, though recent actions to create subsistence-only zones in key herring-spawning habitats in Sitka Sound (as requested by the Sitka Tribe) are an encouraging sign of respect for LTK and its herring-management principles.

These examples demonstrate that there is considerable room for constructive engagement of LTK as part of marine research, monitoring, spatial planning, and conservation. Further steps to enhance its role in improving adaptation and resilience should include: (1) stronger recognition of the relationship between marine biodiversity and the cultural diversity among maritime peoples; (2) acknowledgement of threats and stresses to marine LTK and sustainable livelihoods by historical and contemporary commercial harvesting, development, and environmental change in coastal zones and seascapes; and (3) the nurturing of traditional and collaborative stewardship systems to protect, restore, and enhance the productivity, diversity, and resilience of critical marine ecosystems that support sustainable maritime cultures. 
By reviewing some of the successes and failures in marine LTK-science production, dissemination, policy implementation, and collaborative infrastructure development, we hope that more successful bridging projects and institutions that link local knowledge and science will be conceived, funded, and implemented in order to better inform critical environmental change and adaptive comanagement issues facing marine social-ecological systems today. This is a matter of some urgency, for as Alaskan Yup'ik Eskimo elder John Eric states, drawing on his own people's reservoir of marine LTK: "We cannot live without the ocean. Our ancestors sustained themselves mainly from the ocean .... It's no wonder that the ocean has the name imarpik [from imaq, "contents,"], because it holds everything" (Fienup-Riordan and Reardon 2012:215).

Responses to this article can be read online at: http://www.ecologyandsociety.org/voll7/iss3/art8/responses/

\section{Acknowledgments:}

We are grateful to Oxford University's Environmental Change Institute, School of Geography and Environment for the 2008 internship programme that supported this research. We also would like to thank the editors and reviewers of this manuscript for their valuable suggestions and encouragement.

\section{LITERATURE CITED}

Acheson, J. 1988. The lobster gangs of Maine. University Press of New England, Durham, New Hampshire, USA.

Acheson, J., and J. Wilson. 1996. Order out of chaos:the case for parametric fisheries management. American Anthropologist 98:579-594. http://dx.doi.org/10.1525/aa.1996.98.3.02a00110

Agrawal, A. 1995. Dismantling the divide between indigenous and scientific knowledge. Development and Change 26:413-439. http://dx.doi.org/10.1111/j.1467-7660.1995.tb00560. $\underline{\mathrm{x}}$

Agrawal, A. 2002. Indigenous knowledge and the politics of classification. International Social Science Journal 54:287-297. http://dx.doi.org/10.1111/1468-2451.00382

Aguilar-Perera, A., C. Gonzáles-Salas, A. Tuz-Sulub, and H. Villegas-Hernandez. 2009. Fishery of the Goliath grouper, Epinephelus itajara (Teleostei: Epinephelidae) based on local ecological knowledge and fishery records in Yucatan, Mexico. International Review of Tropical Biology and Conservation 57:557-566.

Aguilar-Perera, A., M. Scharer, and M. Valdes-Pizzini. 2006. Marine protected areas in Puerto Rico: historical and current perspectives. Ocean and Coastal Management 49:961-975. http://dx.doi.org/10.1016/j.ocecoaman.2006.08.011

Akimichi, T. 1978. The ecological aspect of Lau (Solomon Islands) ethnoichthyology. Journal of the Polynesian Society 87:301-326.

Akimichi, T. 1986. Conservation of the sea: Satawal, Micronesia. Pacific Anthropological Records 37:15-34.

Akimichi, T. 2001. Species-oriented community-based resource management: a case study from small-scale fisheries in the Yaeyama islands, southwestern Japan. Pages 109-132 in James McGoodwin, editor. Understanding the cultures of fishing communities: a key to fisheries management and food security. FAO, Rome, Italy.

Akyeampong, E. 2007. Indigenous knowledge and maritime fishing in West Africa: the case of Ghana. Tribes and Tribals (Special Volume) 1:173-182.

Alessa L., A. Kliskey A., P. Williams, and M. Barton. 2008. Perception of change in freshwater in remote resourcedependent Arctic communities. Global Environmental Change 18:153-164. http://dx.doi.org/10.1016/j.gloenvcha.20 $\underline{07.05 .007}$

Almudi, T., and D. Coswig Kalikoski. 2010. Traditional fisherfolk and no-take protected areas: the Peixe Lagoon National Park dilemma. Ocean and Coastal Management 53:225-233. http://dx.doi.org/10.1016/j.ocecoaman.2010.04.005

Alvarez, J., and K. Vodden. 2009. Local ecological knowledge and impacts of global climatic change on the community of seaweed extractors in Pisco-Perú. Pages 1015-1024 in D.F. Kocaoglu, T. R. Anderson, and T. U. Daim, editors. PICMET '09, Portland International Center for Management of Engineering and Technology-proceedings, technology management in the age of fundamental change (Portland, Oregon, USA 2-6 August 2009). IEEE (Institute of Electrical and Electronics Engineers). http://dx.doi.org/10.1109/PICME $\underline{\text { T.2009.5262030 }}$

Ambali, A., H. Kabwazi, L. Malekano, G. Mwale, D. Chimwaza, J. Ingainga, N. Makimoto, S. Nakayama, M. Yuma, and Y. Kada. Y. 2001. Relationship between local and scientific names of fishes in Lake Malawi/Nyasa. African Study Monographs 22:123-154.

Ames, T. 2003. Putting fishermen's knowledge to work: the promise and pitfalls. Pages 184-188 in N. Haggan, C. Brignall, and L. Wood, editors. Putting fishers' knowledge to work, conference proceedings (27-30 August 2011, Vancouver, Canada). Fisheries Centre Research Reports 11:1.

Ames, T. 2007. Putting fishers' knowledge to work: reconstructing the Gulf of Maine cod spawning ground on the 
basis of local ecological knowledge. Pages 353-363 in $\mathrm{N}$. Haggan, B. Neis, and I. G. Baird, editors. Fishers' knowledge in fisheries science and management. Coastal Management Sourcebooks 4. UNESCO, Paris, France.

Ammarell, G. 1995. Navigation practices of the Bugis of South Sulawesi, Indonesia. Pages 196-218 in R. Feinburg, editor. Seafaring in the contemporary Pacific Islands: studies in continuity and change. Northern Illinois University Press, DeKalb, Illinois, USA.

Amos, M. 1993. Traditionally based marine management systems in Vanuatu. SPC Traditional Marine Resource Management and Information Bulletin 2:14-18.

Anderson, E. N. 2007. Floating world lost. University Press of the South, New Orleans, Louisiana, USA.

Ankei, Y. 1989. Folk knowledge of fish among the Songola and the Bwari: comparative ethnoichthyology of the Lualaba River and Lake Tanganyika fishermen. African Study Monographs 9:1-88.

Anuchiracheeva, S., H. Demaine, P. Shivakoti, and K. Ruddle. 2003. Systematizing local knowledge using GIS: fisheries management in Bang Saphan Bay, Thailand. Ocean and Coastal Management 46:1049-1068. http://dx.doi.org/10.1016/ j.ocecoaman.2004.01.001

Aporta, C. 2002. Life on the ice: understanding the codes of a changing environment. Polar Record 38:341-354. http://dx. doi.org/10.1017/S0032247400018039

Aporta, C. 2003. New ways of mapping: using GPS mapping software to plot place names and trails in Igloolik (Nunavut). Arctic 56:321-327.

Aporta, C. 2004. Routes, trails and tracks: trail breaking among the Inuit of Igloolik. Etudes/Inuit/Studies 28:9-38. http://dx.d oi.org/10.7202/013194ar

Aporta, C. 2009. The trail as home: Inuit and their pan-Arctic network of routes. Human Ecology 37:131-146. http://dx.doi. org/10.1007/s10745-009-9213-X

Aporta, C., and E. Higgs. 2005. Global positioning systems, Inuit wayfinding and the new for a new account of technology. Current Anthropology 46:729-753.

Aporta, C., and J. MacDonald. 2011. An elder on sea ice: an interview with Aipilik Inuksuk of Igloolik, Nunavut. The Canadian Geographer 55:32-35. http://dx.doi.org/10.1111/j.1 541-0064.2010.00342.X

Arce-Ibarra, A., and A. Charles. 2008. Inland fisheries of the Mayan zone in Quintana Roo, Mexico: using a combined approach to fishery assessment for data-sparse fisheries. Fisheries Research 91:151-159. http://dx.doi.org/10.1016/j.fi shres.2007.11.015
Armitage, D. R. 2005. Community-based narwhal management in Nunavut, Canada: change, uncertainty and adaptation. Society and Natural Resources 18:715-731. http:/ /dx.doi.org/10.1080/08941920591005124

Armitage, D. R., F. Berkes, and N. Doubleday, editors. 2007. Adaptive co-management: collaboration, learning, and multilevel governance. University of British Columbia Press, Vancouver, British Columbia, Canada.

Ashaletha, S., and S. Immanuel. 2008. Scope of ethnofisheries and sustainable marine fisheries management in India. Indian Journal of Traditional Knowledge 7:226-232.

Aswani, S., A. Albert, A. Sabetian, and T. Furusawa. 2007. Customary management as precautionary and adaptive principles for protecting coral reefs in Oceania. Coral Reefs 26:1009-1021. http://dx.doi.org/10.1007/s00338-007-0277-z

Aswani, S., and R. Hamilton. 2004. Integrating indigenous ecological knowledge and customary sea tenure with marine and social science for conservation of bumphead parrotfish (Bolbometopon muricatum) in the Roviana Lagoon, Solomon Islands. Environmental Conservation 31:69-83. http://dx.doi. org/10.1017/S037689290400116X

Aswani, S., and M. Lauer. 2006. Benthic mapping using local aerial photo interpretation and resident taxa inventories for designing marine protected areas. Environmental Conservation 33:263-273. http://dx.doi.org/10.1017/S0376892906003183

Aswani, S., and I. Vaccaro. 2008. Lagoon ecology and social strategies: habitat diversity and ethnobiology. Human Ecology 36:325-341. http://dx.doi.org/10.1007/s10745-007-9159-9

Baines, G. 1992. Traditional environmental knowledge from the Marovo Area of the Solomon Islands. Pages 83-102 in M. Johnson, editor. Lore: capturing traditional environmental knowledge. Dene Cultural Institute, International Development Research Centre, Hay River, Northwest Territories, Canada.

Baines, G., and E. Hviding. 1993.Traditional knowledge for resource management in Marovo, Soloman Islands. Pages 56-68 in N. Williams and G. Baines, editors. Traditional ecological knowledge: wisdom for sustainable development. Australian National University, Canberra, Australia.

Baird, I., and M. Flaherty M. 2005. Mekong River fish conservation zones in Southern Laos: assessing effectiveness using local ecological knowledge. Environmental Management 36:439-454. http://dx.doi.org/10.1007/s00267-005-3093-7

Ban, N., C. Picard, and A. Vincent. 2008. Moving towards spatial solutions in marine conservation with indigenous communities. Ecology and Society 13(1): 32. [online] URL: http://www.ecologyandsociety.org/vol13/iss1/art32/. 
Ban, N., C. Picard, and A. Vincent. 2009. Comparing and integrating community-based and science-based approaches to prioritizing marine areas for protection. Conservation Biology 23:899-910. http://dx.doi.org/10.1111/j.1523-1739.2 009.01185.x

Barber, D., M. Asplin, Y. Gratton, J. Lukovich, R. Galley, R. Raddatz, and D. Leitch. 2010. The international polar year (IPY) circumpolar flaw lead (CFL) system study: overview and the physical system. Atmosphere Ocean 48:225-243.

Bart, D. 2006. Integrating local ecological knowledge and manipulative experiments to find the causes of environmental change. Frontiers in Ecology and Environment 4:541-546. http://dx.doi.org/10.1890/1540-9295(2006)4[541:ILEKAM]2.0. $\mathrm{CO} ; 2$

Batista, V., and L. Lima. 2010. In search of traditional bioecological knowledge useful for fisheries co-management: the case of jaraquis Semaprochilodus spp. (Characiformes, Prochilodontidaeo) in Central Amazon, Brazil. Journal of Ethnobiology and Ethnomedicine 6:15-24. http://dx.doi.org/1 $\underline{0.1186 / 1746-4269-6-15}$

Bergmann, M., H. Hinz, R. Blyth, M. Kaiser, S. Rogers, and M. Armstrong. 2004. Using knowledge from fishers and fisheries scientists to identify possible groundfish 'essential fish habitats'. Fisheries Research 66:373-379. http://dx.doi.o rg/10.1016/j.fishres.2003.07.007

Berkes, F. 1977. Fishery resource use in a subarctic Indian community. Human Ecology 5:289-308. http://dx.doi.org/10. $\underline{1007 / B F 00889173}$

Berkes, F. 2008. Sacred ecology. Taylor and Francis, Philadelphia, Pennsylvania, USA.

Berkes, F. 2009a. Evolution of co-management: role of knowledge generation, bridging organisations and social learning. Journal of Environmental Management 90:1692-1702. http://dx.doi.org/10.1016/j.jenvman.2008.12.001

Berkes, F. 2009b. Social aspects of fisheries management. Pages 52-74 in K. Cochrane and S. Garcia, editors. A fishery manager's guidebook. Second edition. FAO, Rome, Italy.

Berkes, F., M. Berkes, and H. Fast. 2007. Collaborative integrated management in Canada's North: the role of local and traditional knowledge and community-based monitoring. Coastal Management 35:143-162. http://dx.doi.org/10.1080/0 8920750600970487

Berkes, F., J. Colding, and C. Folke. 2000. Rediscovery of traditional ecological knowledge as adaptive management. Ecological Applications 10:1251-1262. http://dx.doi.org/10.1 890/1051-0761(2000)010[1251:ROTEKA]2.0.CO;2

Berkes, F., C. Folke, and M. Gadgil. 1995. Chapter 15: Traditional ecological knowledge, biodiversity, resilience and sustainability. Pages 281-299 in C. A. Perrings, K. G. Mäler, C. Folke, B. O. Jansson, and C. S. Holling editors. Biodiversity conservation. Kluwer Academic Publishers, Dordrecht, The Netherlands.

Berkes, F., R. Mahon, P. McConney, R. Pollnac, and R. Pomeroy. 2001a. Managing small-scale fisheries: alternative directions and methods. International Development Research Centre, Ottawa, Ontario, Canada.

Berkes, F., J. Mathias, M. Kislalioglu, and H. Fast. 2001b. The Canadian Arctic and the Oceans Act: the development of participatory environmental research and management. Ocean and Coastal Management 44:451-469. http://dx.doi.org/10.10 16/S0964-5691(01)00060-6

Berkes, F., and N. Turner. 2006. Knowledge, learning and the evolution of conservation practice for social-ecological system resilience. Human Ecology 34:479-494.

Biswas, S., A. Mallik, J. Choudhoury, and A. Nishat. 2009. A united framework for the restoration of Southeast Asian mangroves-bridging ecology, society and economics. Wetlands Ecology and Management 17:365-383. http://dx.doi. org/10.1007/s11273-008-9113-7

Bjarnason, T., and T. Thorlindsson. 1993. In defense of a folk model: the 'skipper effect' in the Icelandic cod fishery. American Anthropologist 95:371-374. http://dx.doi.org/10.1525/ aa.1993.95.2.02a00060

Blount, B. 2005. Small-scale fisheries in the contemporary world: adaptation and management. Reviews in Anthropology 34:1-19. http://dx.doi.org/10.1080/00938150590915023

Bonny, E., and F. Berkes. 2008. Communicating traditional environmental knowledge: addressing the diversity of knowledge, audiences and media types. Polar Record 44:243-253. http://dx.doi.org/10.1017/S0032247408007420

Boomhower, J., M. Romero, J. Posada, S. Kobara, and W. Heyman. 2007. Identification of reef fish spawning aggregation sites in Los Roques Archipelago National Park, Venezuela. Pages 559-565 in Proceedings of the $60^{\text {th }}$ Gulf and Caribbean Fisheries Institute (November 5-9 2007, Punta Cana, Dominican Republic).

Brook, R., and S. McLachlan. 2008. Trends and prospects for local knowledge in ecological and conservation research and monitoring. Biodiversity Conservation 17:3501-3512. http://d x.doi.org/10.1007/s10531-008-9445-X

Burenhult, N. 2008. Streams of words: hydrological lexicon in Jahai. Language Sciences 30:182-199. http://dx.doi.org/10 .1016/j.langsci.2006.12.005

Cablitz, G. 2008. What "what" is "where": a linguistic analysis of landscape terms, place names and body part terms, place 
names and body part terms in Marquesan (Oceanic, French Polynesia). Language Sciences 30:200-226. http://dx.doi.org/ 10.1016/j.langsci.2006.12.004

Calamia, M. 1999. A methodology for incorporating traditional ecological knowledge with geographic information systems for marine resource management in the Pacific. SPC Traditional Marine Resource Management and Knowledge Information Bulletin 10:13.

Carmack, E., and R. Macdonald. 2008. Water and ice-related phenomena in the coastal region of the Beaufort Sea: some parallels between native experience and Western science. Arctic 61:255-280.

Carter, B., and E. Nielsen. 2011. Exploring ecological changes in Cook Inlet beluga whale habitat through traditional and local ecological knowledge of contributing factors for population decline. Marine Policy 35:299-208. http://dx.doi.o rg/10.1016/j.marpol.2010.10.009

Castellanos-Galindo, G., J. Cantera, S. Espinosa, and L. M. Mejia-Ladino. 2011. Use of local ecological knowledge, scientist's observations and grey literature to assess marine species at risk in a tropical eastern Pacific estuary. Aquatic Conservation: Marine and Freshwater Ecosystems 21:37-48. http://dx.doi.org/10.1002/aqc.1163

Cavaleri Gerhardinger, L., E. Godoy, and P. Jones. 2009a. Local ecological knowledge and the management of marine protected areas in Brazil. Ocean and Coastal Management 52:154-165. http://dx.doi.org/10.1016/j.ocecoaman.2008.12.007

Cavaleri Gerhardinger, L., M. Hostim-Silva, R. Pereira Medeiros, J. Matarezi, A. A. Bertoncini, M. F. Oliveira, and B. Padovani Ferreira. 2009b. Fishers' resource mapping and goliath grouper Epinephelus itajara (Serranidae) conservation in Brazil. Neotropical Ichthyology 7:93-102. http://dx.doi.org /10.1590/S1679-62252009000100012

Cavaleri Gerhardinger, L., R. Marenzi Carvalho, A. A. Bertoncini, R. Medeiros, and M. Hostim-Silva. 2006. Local ecological knowledge on the Goliath Grouper Epinelphelus itajara (Teleostei: Serranidae) in Southern Brazil. Neotropical Ichthyology 4:441-450.

Chapman, M. 1987. Women's fishing in Oceania. Human Ecology 15:267-289. http://dx.doi.org/10.1007/BF00888026

Cinner, J., T. McClanahan, and A. Wamukota. 2010. Differences in livelihoods, socioeconomic characteristics, and knowledge about the sea between fishers and non-fishers living near and far from marine parks on the Kenyan coast. Marine Policy 34:22-28. http://dx.doi.org/10.1016/j.marpol.2 009.04.003
Close, C., and B. Hall. 2006. A GIS-based protocol for the collection and use of local knowledge in fisheries management planning. Journal of Environmental Management 78:341-352. http://dx.doi.org/10.1016/j.jenvman.2005.04.027

Conklin, H. 1957. Hanunóo agriculture: an example of shifting cultivation in the Philippines. Unasylva 11:4.

Cordell, J. 1974. The lunar-tide fishing cycle in northeastern Brazil. Ethnology 13:379-392. http://dx.doi.org/10.2307/3773053

Coulthard, S. 2011. More than just access to fish: the pros and cons of fisher participation in a customary marine tenure (Padu) system under pressure. Marine Policy 35:405-412. http://dx.doi.org/10.1016/j.marpol.2010.11.006

Crona, B. 2006. Supporting and enhancing development of heterogenous ecological knowledge among resource users in a Kenyan seascape. Ecology and Society 11(1): 32. [online] URL: http://www.ecologyandsociety.org/vol11/iss1/art32/.

Crona, B., and O. Bodin. 2006. What you know is who you know? Communication patterns among resource users as a prerequisite for co-management. Ecology and Society 11(2): 7. http://www.ecologyandsociety.org/vol11/iss2/art07/

Crona, B., and O. Bodin. 2010. Power asymmetries in smallscale fisheries: a barrier to governance transformability? Ecology and Society 15(4): 32. http://www.ecologyandsociety. org/vol15/iss4/art32/

Cruikshank, J. 2001. Glaciers and climate change: perspectives from oral tradition. Arctic 54, 377-393.

Cruikshank, J. 2005. Do glaciers listen? Local knowledge, colonial encounters, and social imagination. University of British Columbia Press, Vancouver, British Columbia, Canada.

Dale, A., and D. Armitage. 2011. Marine mammal comanagement in Canada's Arctic: knowledge co-production for learning and adaptive capacity. Marine Policy 35:440-449. http://dx.doi.org/10.1016/j.marpol.2010.10.019

Davis, A., J. Hanson, H. Watts, and H. MacPherson. 2004. Local ecological knowledge and marine fisheries research: the case of white hake (Urophycis tenuis) predation on juvenile American lobster (Homarus americanus). Canadian Journal of Fisheries and Aquatic Science 61:1191-1201. http://dx.doi. org/10.1139/f04-070

Daw, T., J. Robinson, and N. Graham. 2011. Perceptions of trends in Seychelles artisanal trap fisheries: comparing catch monitoring, underwater visual census and fishers' knowledge. Environmental Conservation 38:75-88. http://dx.doi.org/10.1 $\underline{017 / S 0376892910000901}$

Demunshi, Y., and A. Chugh. 2010. Role of traditional knowledge in marine bioprospecting. Biodiversity and 
Conservation 19:3015-3033. http://dx.doi.org/10.1007/s1053 1-010-9879-9

Dowsley, M. 2009. Community clusters in wildlife and environmental management: using TEK and community involvement to improve co-management in an era of rapid environmental change. Polar Research 28:43-59. http://dx.do i.org/10.1111/j.1751-8369.2008.00093.x

Dowsley, M., and G. Wenzel. 2008. "The time of the most polar bears": a co-management conflict in Nunavut. Arctic 61:177-189.

Drew, J. 2005. Use of traditional ecological knowledge in marine conservation. Conservation Biology 19:1286-1293. http://dx.doi.org/10.1111/j.1523-1739.2005.00158.x

Dulvy, N., and N. Polunin. 2004. Using informal knowledge to infer human-induced rarity of a conspicuous reef fish. Animal Conservation:365-374. http://dx.doi.org/10.1017/S13 $\underline{67943004001519}$

Eddy, T., Gardner, J., and A. Pérez-Matus. 2010. Applying fishers' ecological knowledge to construct past and future lobster stocks in the Juan Fernández Archipelago, Chile. PLoS One 5:1-13. http://dx.doi.org/10.1371/journal.pone.0013670

Ellis, S. 2005. Meaningful consideration? A review of traditional knowledge in environmental decision-making. Arctic 58:66-77.

Espinoza-Tenorio, A., G. Montaño-Moctezuma, and I. Espejel. 2010. Ecosystem-based analysis of a marine protected area where fisheries and protected species coexist. Environmental Management 45:739-750. http://dx.doi.org/10 $.1007 / \mathrm{s} 00267-010-9451-0$

Evans, L. 2010. Ecological knowledge interactions in marine governance in Kenya. Ocean \& Coastal Management 53:180-191. http://dx.doi.org/10.1016/j.ocecoaman.2010.01.009

Feinberg, R. 1988. Polynesian seafaring and navigation: ocean travel in Anutan culture and society. Kent State University Press, Kent, Ohio, USA.

Feinberg, R. 1995. Continuity and change in Nukumanu maritime technology and practice. Pages 159-195 in R. Feinburg, editor. Seafaring in the contemporary Pacific Islands: studies in continuity and change. Northern Illinois University Press, DeKalb, Illinois, USA.

Felt, L. 1994. Two tales of a fish: the social construction of indigenous knowledge among Atlantic Canadian salmon fishers. Pages 251-286 in C. Dyer and J. McGoodwin, editors. Folk management of the world's fisheries: lessons for modern fisheries management. University Press of Colorado, Niwot, Colorado, USA.
Felt, L. 2008. "It all depends on the lens, b'y": local ecological knowledge and institutional science in an expanding finfish aquaculture sector. Pages 167-190 in K. Culver and D. Castle, editors. Aquaculture, innovation and social transformation. The International Library of Environmental, Agricultural and Food Ethics 17. Springer Science and Business Media.

Fernandez-Giminez, M., H. Huntington, and K. Frost. 2006. Integration or co-optation? Traditional knowledge and science in the Alaska Beluga Whale Committee. Environmental Conservation 33:306-315. http://dx.doi.org/10.1017/S037689 $\underline{2906003420}$

Ferse, S., M. Máñez Costa, K. Schwerdtner Máñez, D. Adhuri, and M. Glaser. 2010. Allies, not aliens: increasing the role of local communities in marine protected area management. Environmental Conservation 37:23-34. http://dx.doi.org/10.1 $\underline{017 / S 0376892910000172}$

Fienup-Riordan, A. 1999. Yaqulget qaillun pilartat (what the birds do): Yup'ik Eskimo understanding of geese and those who study them. Arctic 1:1-22.

Fienup-Riordan, A., and A. Reardon. 2012. Ellavut: our Yup'ik world and weather: continuity and change on the Bering Sea coast. University of Washington Press and Calista Elders Council, Seattle, Washington, USA.

Fiji Locally Managed Marine Areas Network (FLMMA). 2011. The way we work together: guidelines for members of the FLMMA network, final 1.7 March 2011. FLMMA Operations Guide. Institute of Applied Sciences, Faculty of Science Technology and Environment, University of the South Pacific, Suva, Fiji.

Finney, B. 1976. Pacific navigation and voyaging. The Polynesian Society, Auckland, New Zealand.

Foale, S. 1998. Assessment and management of the trochus fishery at West Nggela, Soloman Islands: an interdisciplinary approach. Ocean and Coastal Management 40:187-205. http: //dx.doi.org/10.1016/S0964-5691(98)00044-1

Foale, S. 2006a. The intersection of scientific and indigenous ecological knowledge in coastal Melanesia: implications for contemporary marine resource management. International Social Science 58:129-137. http://dx.doi.org/10.1111/j.14682451.2006.00607.x

Foale, S. 2006b. Is coral reef conservation possible without science education in Melanesia? Is science education possible without development? Pages 1274-1278 in Y. Suzuki, T. Nakamori, M. Hidaka, H. Kayanne, B. E. Casareto, K. Nadaoka, H. Yamano, and M. Tsuchiya, editors. Proceedings of the 10th International Coral Reef Symposium (28 June -2 July 2004, Okinawa, Japan). Japanese Coral Reef Society, Tokyo, Japan. 
Forman, S. 1967. Cognition and the catch: the location of fishing spots in a Brazilian coastal village. Ethnology 6:417-426. http://dx.doi.org/10.2307/3772828

Forman, S. 1970. The raft fishermen: tradition and change in the Brazilian peasant economy. Indiana University Press, London, UK.

Garcia-Quijano, C. 2007. Fishers' knowledge of marine species assemblages: bridging between scientific and local ecological knowledge in Southeastern Puerto Rico. American Anthropologist 109:529-536. http://dx.doi.org/10.1525/aa.200 7.109.3.529

Garcia-Quijano, C. 2009. Managing complexity: ecological knowledge and success in Puerto Rican small-scale fisheries. Human Organisation 68:1-17.

Gearheard, S., C. Aporta, G. Aipellee, and K. O'Keefe. 2011. The Igliniit project: Inuit hunters document life on the trail to map and monitor arctic change. The Canadian Geographer 55(1):42-55. http://dx.doi.org/10.1111/j.1541-0064.2010.00344. $\underline{\mathrm{X}}$

Gearheard, S., W. Matumeak, I. Angutikjuaq, H. Maslanik, H. Huntington, J. Leavitt, D. Matumeak Kagak, G. Tigullaraq, and R. Barry. 2006. 'It's not that simple': a collaborative comparison of sea ice environments, their uses, observed changes and adaptations in Barrow, Alaska, USA, and Clyde River, Nunavut, Canada. Ambio 35:203-212. http://dx.doi.org /10.1579/0044-7447(2006)35[203:INTSAC]2.0.CO;2

Gearheard, S., and J. Shirley. 2007. Challenges in communityresearch relationships: learning from natural science in Nunavut. Arctic 60:62-74.

George, J., Huntington, H., Brewster, K., Eicken, H., Norton, D., and R. Glenn. 2004. Observations on shorefast ice dynamics in Arctic Alaska and the responses of the Inupiat hunting community. Arctic 57:363-374.

Gilchrist, G., and G. Robertson. 2000. Observations of marine birds and mammals wintering at polynyas and ice edges in the Belcher Islands, Nunavut, Canada. Arctic 53:61-68.

Gladwin, T. 1970. East is a big bird: navigation and logic on Puluwat Atoll. Harvard University Press, Cambridge, Massachusetts, USA.

Gosse, K., J. Wroblewski, and B. Neis. 2003. Closing the loop: commercial fish harvesters' local ecological knowledge and science in a study of coastal cod in Newfoundland and Labrador, Canada. Pages 25-36 in N. Haggan, C. Brignall, and L. Wood, editors. Putting fishers' knowledge to work, conference proceedings (27-30 August 2011, Vancouver, Canada). Fisheries Centre Research Reports 11:1.

Grant, S., and F. Berkes. 2007. Fisher knowledge as expert system: a case from the longline fishery of Grenada, the eastern
Caribbean. Fisheries Research 84:162-170. http://dx.doi.org/ 10.1016/j.fishres.2006.10.012

Hall, B. G., A. Moore, P. Knight, and N. Hankey. 2009. The extraction and utilization of local and scientific geospatial knowledge within the Bluff oyster fishery, New Zealand. Journal of Environmental Management 90:2055-2070. http:// dx.doi.org/10.1016/j.jenvman.2007.08.022

Hamilton, R. 2005. Indigenous ecological knowledge of the aggregating and nocturnal spawning behaviour of the longfin emperor, Lethrinus erythropterus. SPC Traditional Marine Resource Management and Knowledge Information Bulletin 18:9-18.

Hamilton R., and R. Walter. 1999. Indigenous ecological knowledge and its role in fisheries research design: a case study from the Roviana Lagoon, Western Province, Solomon Islands. Traditional Marine Resource Management and Knowledge Information Bulletin 11:13-21.

Harnish, L., and J. Martin Willison. 2009. Efficiency of bait usage in the Nova Scotia lobster fishery: a first look. Journal of Cleaner Production 17:345-347. http://dx.doi.org/10.1016/ j.jclepro.2008.08.005

Heaslip, R. 2008. Monitoring salmon aquaculture waste: the contribution of First Nations' rights, knowledge and practices in British Columbia, Canada. Marine Policy 32:988-996. htt p://dx.doi.org/10.1016/j.marpol.2008.02.002

Henshaw, A. 2009. Sea ice: the sociocultural dimensions of a melting environment in the Arctic. In S. Crate and M. Nuttall, editors. Anthropology and climate change: from encounters to action. Left Coast Press, Walnut Creek, California, USA.

Hernandez Cornejo, R., N. Koedam, A. Ruiz Luna, M. Troell, and F. Dahdouh-Guebas. 2005. Remote sensing and ethnobotanical assessment of the mangrove forest changes in the Navchiste-San Ignacio-Macapule Lagoon Complex, Sinaloa, Mexico. Ecology and Society 10(1) 16. [online] URL: http://www.ecologyandsociety.org/vol10/iss1/art16/.

Heyes, S. 2011. Cracks in the knowledge: sea ice terms in Kangiqsualujjuaq, Nunavik. Canadian Geographer 55:69-90. http://dx.doi.org/10.1111/j.1541-0064.2010.00346.x

Hickey, F. 2007. Traditional marine resource management in Vanuatu: worldviews in transformation. Pages 147-168 in N. Haggan, B. Neis and I. Baird, editors. Fishers' knowledge in fisheries science and management. Coastal Management Sourcebooks 4. UNESCO, Paris, France.

Hill, N., K. Michael, A. Frazer, and S. Leslie. 2010. The utility and risk of local ecological knowledge in developing stakeholder driven fisheries management: the Foveaux Strait dredge fishery, New Zealand. Ocean and Coastal Management 53:659-668. http://dx.doi.org/10.1016/j.ocecoam an.2010.04.011 
Hunn, E., D. Johnson, P. Russell, and T. Thornton. 2003. Huna Tlingit traditional environmental knowledge, conservation, and the management of a "wilderness" park. Current Anthropology 44S: S79-S103. http://dx.doi.org/10.1086/377666

Huntington, H., P. Brown-Schwalenberg, K. Frost, M. Fernandez-Giminez, D. Norton, and D. Rosenberg. 2002. Observations on the workshop as a means of improving communication between holders of traditional and scientific knowledge. Environmental Management 30:778-792. http://d x.doi.org/10.1007/s00267-002-2749-9

Huntington, H., and the Communities of Buckland, Elim, Koyuk, Point Lay, and Shaktoolik. 1999. Traditional knowledge of the ecology of beluga whales (Delphinapterus leucas) in the eastern Chukchi and northern Bering Seas, Alaska. Arctic 52:49-61.

Huntington, H., R. Suydam, and D. Rosenberg. 2004. Traditional knowledge and satellite tracking as complementary approaches to ecological understanding. Environmental Conservation 31:177-180. http://dx.doi.org/10.1017/S037689 $\underline{2904001559}$

Huntington, H.P. 1992. Wildlife management and subsistence hunting in Alaska. Belhaven Press, London, UK.

Hviding, E. 1996. Guardians of Marovo Lagoon: practice, plans and politics in maritime Melanesia. University of Hawaii Press, Honolulu, Hawaii, USA.

Igarashi, T. 1984. Locality-finding in relation to fishing activities at sea. In B. Gunda, editor. The fishing cultures of the world: studies in ethnology, cultural ecology and folklore. Akademiai Kiado, Budapest, Hungary.

Inuksuk, A. 2011. On the nature of sea ice around Igloolik. Canadian Geographer 55:36-41. http://dx.doi.org/10.1111/j.1 541-0064.2010.00343.X

Jewett, S., L. Clough, A. Blanchard, W. Ambrose, H. Feder, M. Hoberg, and A. Whiting. 2009. Nearshore macrobenthos of northern Kotzebue Sound, Alaska, with reference to local sewage disposal. Polar Biology 32:1665-1680. http://dx.doi.o rg/10.1007/s00300-009-0667-5

Johannes R., and B. Neis. 2007. The value of anecdote. Pages 41-58 in N. Haggan, B. Neis, and I. Baird, editors. Fishers' knowledge in fisheries science and management. Coastal Management Sourcebooks 4. UNESCO, Paris, France.

Johannes, R., and B. Yeeting. 2000. I-Kiribati knowledge and management of Tarawa's lagoon reserves. Atoll Research Bulletin 489.

Johannes, R. E. 1978. Traditional marine conservation methods in Oceania and their demise. Annual Review of Ecology and Systematics 9:349-364. http://dx.doi.org/10.1146/ annurev.es.09.110178.002025
Johannes, R. E. 1981. Words of the lagoon: fishing and marine lore in the Palau District of Micronesia. University of California Press, Berkeley, California, USA.

Johannes, R. E. 1998. Government-supported, village-based management of marine resources in Vanuatu. Ocean and Coastal Management 40:165-186. http://dx.doi.org/10.1016/S 0964-5691(98)00046-5

Johannes, R. E. 2002. The renaissance of community-based marine resource management in Oceania. Annual Review of Ecology and Systematics 33:317-340. http://dx.doi.org/10.1146/ annurev.ecolsys.33.010802.150524

Johannes, R. E., and J. MacFarlane. 1991. Traditional fishing in the Torres Strait Islands. CSIRO Division of Fisheries, Hobart, Australia.

Jones, R. 2007. Application of Haida oral history to Pacific herring management. Pages 103-118 in N. Haggan, B. Neis, and I. Baird, editors. Fishers' knowledge in fisheries science and management. Coastal Management Sourcebooks 4. UNESCO, Paris, France.

Jones, R., C. Rigg, and L. Lee. 2010. Haida marine planning: First Nations as a partner in marine conservation. Ecology and Society 15(1): 12. [online] URL: http://www.ecologyandsociety. org/vol15/iss1/art12/.

Jones, R. R., and T-L. Williams-Davidson. 2000. Applying Haida ethics in today's fishery. Pages 87-94 in S. W. Fair and R. World, editors. Celebration 2000: restoring balance through culture. Sealaska Heritage Foundation, Juneau, Alaska, USA.

Keith, D., Arqviq, J., Kamookak, L., and J. Ameralik. 2005. Inuit Qaujimaningit Nanurnut: Inuit knowledge of polar bears. Gjoa Haven Hunters' and Trappers' Organization; and CCI Press, University of Calgary; Calgary, Alberta, Canada.

Klee, G. 1980. Oceania. Pages 283-285 in G. Klee, editor. World systems of traditional resource management. Edward Arnold, London, UK.

Knopp, J. 2010. Investigating the effects of environmental change on Arctic char (Salvelinus alpinus) growth using scientific and Inuit traditional knowledge. Arctic 63:493-497.

Knudsen, S. 2008. Ethical know-how and traditional ecological knowledge in small scale fisheries on the eastern Black Sea coast of Turkey. Human Ecology 36:29-41. http:// dx.doi.org/10.1007/s10745-007-9134-5

Knutsen, J. A., H. Knutsen, E. Rinde, H. Christie, T. Bodvin, and E. Dahl. 2010. Mapping biological resources in the coastal zone: an evaluation of methods in a pioneering study from Norway. Ambio 39:148-158. http://dx.doi.org/10.1007/s1328 0-010-0023-6

Kovacs, J. 2000. Perceptions of environmental change in a tropical coastal wetland. Land Degradation and Development 
11:209-220. http://dx.doi.org/10.1002/1099-145X(200005/06) 11:3<209::AID-LDR378>3.0.CO;2-Y

Krupnik, I. 2002. Watching ice and weather our way: some lessons from Yupik observations of sea ice and weather on St. Lawrence Island. Pages 156-197 in I. Krupnik and D. Jolly, editors. The Earth is faster now: indigenous observations of Arctic environmental change. ARCUS, Fairbanks, Alaska, USA.

Krupnik, I. 2011. 'How many Eskimo words for ice?' Collecting Inuit sea ice terminologies in the international polar year 2007-2008. The Canadian Geographer 55:56-68. http:// dx.doi.org/10.1111/j.1541-0064.2010.00345.x

Krupnik, I., C. Aporta, S. Gearheard, G. J. J. Laidler, and L. Kielsen Holm, editors. 2010. SIKU: knowing our ice, documenting sea-ice knowledge and use. Dodrecht, London, UK.

Krupnik I., and G. Carleton Ray. 2007. Pacific walruses, indigenous hunters, and climate change: bridging scientific and indigenous knowledge. Deep-Sea Research II 54:2946-2957. http://dx.doi.org/10.1016/j.dsr2.2007.08.011

Krupnik, I., and W. U. Weyapuk. 2010. Qanuq Ilitaavut: "How we learned what we know" (Wales Inupiaq sea ice dictionary). Pages 321-354 in I. Krupnik, C. Aporta, S. Gearheard, G. J. J. Laidler, and L. K. Kielsen Holm, editors. SIKU: knowing our ice, documenting sea-ice knowledge and use. Dodrecht, London, UK. http://dx.doi.org/10.1007/978-90-481-8587-0 14

Kurien, J. 1998. Traditional ecological knowledge and ecosystem sustainability: new meaning to Asian coastal proverbs. Ecological Applications 8:S2-S5.

Kurien, J. 2001. The socio-cultural aspects of fisheries: implications for food and livelihood security - a case study of Kerala State, India. Pages 195-218 in J. McGoodwin, editor. Understanding the cultures of fishing communities: a key to fisheries management and food security. FAO, Rome, Italy.

Laidler, G. 2006. Inuit and scientific perspectives on the relationship between sea ice and climate change: the ideal complement? Climatic Change 78:407-444.

Laidler, G., and P. Elee. 2008. Human geographies of sea ice: freeze/thaw processes around Cape Dorset, Nunavut, Canada. Polar Record 44:51-76.

Laidler, G., T. Hirose, M. Kapfer, T. Ikummaq, E. Joamie, and P. Elee. 2011. Evaluating the floe edge service: how well can SAR imagery address Inuit community concerns around sea ice change and travel safety? The Canadian Geographer 55:91-107.

Laidler, G., and T. Ikummaq. 2008. Human geographies of sea ice: freeze/thaw processes around Igloolik, Nunavut,
Canada. Polar Record 44:127-153. http://dx.doi.org/10.1111/ j.1541-0064.2010.00347.x

Landgon, S. 2006. Selective traditional Tlingit salmon fishing techniques on the west coast of the Princes of Wales Archipelago. Pages 22-46 in C. Menzies, editor. Traditional ecological knowledge and natural resource management. University of Nebraska Press, Lincoln, Nebraska, USA.

Lauer M., and S. Aswani. 2008. Integrating indigenous ecological knowledge and multi-spectral image classification for marine habitat mapping in Oceania. Ocean and Coastal Management 51:495-504. http://dx.doi.org/10.1016/j.ocecoam an.2008.04.006

Lauer, M., and S. Aswani. 2010. Indigenous knowledge and long-term ecological change: detection, interpretation and response to changing ecological conditions in Pacific island communities. Environmental Management 45:985-997. http:/ /dx.doi.org/10.1007/s00267-010-9471-9

Lavides, M., N. Polunin, S. Stead, D. G. Tabaranza, M. T. Comeros, and J. R. Dongallo. 2009. Finfish disappearances around Bohol, Philippines inferred from traditional ecological knowledge. Environmental Conservation 36:235-244. http://d x.doi.org/10.1017/S0376892909990385

Leduc, T. 2007. Sila dialogues on climate change: Inuit wisdom for a cross-cultural interdisciplinarity. Climatic Change 85:237-250. http://dx.doi.org/10.1007/s10584-006-9187-2

Lefale, P. F. 2010. Ua 'afa le Aso stormy weather today: traditional ecological knowledge of weather and climate: the Samoa experience. Climatic Change 100:317-335. http://dx.d oi.org/10.1007/s10584-009-9722-z

Lemelin, R. H., B. Walmark, G. Hunter, M. Gull, Washaho First Nations at Fort Severn, and Weenusk First Nation at Peawanuck. 2010. Wabusk of the Omushkegouk: Cree-polar bear (Ursus maritimus) interactions in northern Ontario. Human Ecology 38:803-815.

Levinson, S. 2008. Landscape, seascape and the ontology of places on Rossel Island, Papua New Guinea. Language Science 30:256-290. http://dx.doi.org/10.1016/j.langsci.2006 .12 .032

Linkous Brown, K. 2006. As it was in the past: a return to the use of live-capture technology in the aboriginal riverine fishery. Pages 47-63 in C. Menzies, editor. Traditional ecological knowledge and natural resource management. University of Nebraska Press, Lincoln, Nebraska, USA.

Lobo, A., A. Balmford, R. Arthur, and A. Manica. 2010. Commercializing bycatch can push a fishery beyond economic extinction. Conservation Letters 3:277-285. http://dx.doi.org/ 10.1111/j.1755-263X.2010.00117.x 
Mackinson, S. 2001. Integrating local and scientific knowledge: an example in fisheries science. Environmental Management 27:533-545. http://dx.doi.org/10.1007/s0026700 $\underline{10168}$

Malinowski, B. 1922. Argonauts of the western Pacific. G. Routledge and Kegan Paul PLC, London, UK.

Mallory, M. L., A. J. Fontaine, J. A. Akearok, and V. H. Johnston. 2006. Synergy of local ecological knowledge, community involvement and scientific study to develop marine wildlife areas in eastern Arctic Canada. Polar Record 42:205-216. http://dx.doi.org/10.1017/S0032247406005481

Mallory, M. L., H. G. Gilchrist, A. J. Fontaine, and J. A. Akearok. 2003. Local ecological knowledge of ivory gull declines in Arctic Canada. Arctic 56:293-298.

Manajarréz-Martínez, L., J. C. Gutiérrez-Estrada, J. MazenetGonzález, and M. Sorigeur. 2010. Seasonal patterns of three fish species in a Caribbean coastal gill-net fishery: biologically induced or climate-related aggregations? Fisheries Research 106:358-367. http://dx.doi.org/10.1016/j.fishres.2010.09.005

Mangahas, M. 2010. Seasonable ritual and the regulation of fishing in Batanes Province, Philippines. Pages 77-98 in K. Ruddle and A. Satria, editors. Managing coastal and inland waters: pre-existing aquatic management systems in southeast Asia. Springer, New York, New York, USA. http://dx.doi.org $\underline{\text { 110.1007/978-90-481-9555-8 } 4}$

Manna, R. K., and B. K. Bhattacharjya. 2009. Incorporation of new construction material into indigenous technological knowledge-a case study of V shaped fish trap in eastern India. Indian Journal of Traditional Knowledge 8:548-550.

Mathooko, J. 2005. Application of traditional ecological knowledge in the management and sustainability of fisheries in East Africa: a long-neglected strategy? Hydrobiologia 537:1-6. http://dx.doi.org/10.1007/s10750-004-2788-8

Mauro F., and P. Hardison. 2000. Traditional knowledge of indigenous and local communities: international debate and policy initiatives. Ecological Applications 10:1263-1269. htt p://dx.doi.org/10.1890/1051-0761(2000)010[1263:TKOIAL] 2.0.CO;2

Maurstad, A. 2002. Fishing in murky waters-ethics and politics of research on fisher knowledge. Marine Policy 26:159-166. http://dx.doi.org/10.1016/S0308-597X(01)00045-8

McAdoo, B., A. Moore, and J. Baumwoll. 2009. Indigenous knowledge and the near field population response during the 2007 Solomon Islands tsunami. Natural Hazards 48:73-82. http://dx.doi.org/10.1007/s11069-008-9249-z
McClanahan, T., and J. Cinner. 2008. A framework for adaptive gear and ecosystem-based management in the artisanal coral reef fishery of Papua New Guinea. Aquatic Conservation: Marine and Freshwater Systems 18:492-507. http://dx.doi.org/10.1002/aqc.874

McClanahan, T., H. Glaesel, J. Rubens, and R. Kiambo. 1997. The effects of traditional fisheries management on fisheries yields and the coral-reef ecosystems of southern Kenya. Environmental Conservation 24:105-120. http://dx.doi.org/10 $.1017 /$ S0376892997000179

McGoodwin, J. 2001. Understanding the cultures of fishing communities: a key to fisheries management and food security. FAO Report No. 401. FAO, Rome, Italy.

Memon, P., B. Sheeran, and T. Ririnui. 2003. Between local indigenous communities and their customary fisheries in Aotearoa/New Zealand. Local Environment 8:205-219.

Menzies C., and C. Butler. 2007. Returning to selective fishing through indigenous fisheries knowledge: the example of K'moda, Gitxaala Territory. American Indian Quarterly 31:441-466. http://dx.doi.org/10.1353/aiq.2007.0035

Metcalf, V., and M. Robards. 2008. Sustaining a healthy human-walrus relationship in a dynamic environment: challenges for comanagement. Ecological Applications 18: S148-S156. http://dx.doi.org/10.1890/06-0642.1

Moller, H., F. Berkes, P. O. Lyver, and M. Kislalioglu. 2004. Combining science and traditional ecological knowledge: monitoring populations for co-management. Ecology and Society 9(3): 2. [online] URL: http://www.ecologyandsociety. org/vol9/iss3/art2/.

Moller, H., K. Charleton, B. Knight, and P. Lyver. 2009a. Traditional ecological knowledge and scientific inference of prey availability: harvests of sooty shearwater (Puffinus griseus) chicks by Rakiura Maori. New Zealand Journal of Zoology 36:259-274. http://dx.doi.org/10.1080/03014220909 $\underline{510154}$

Moller, H., P. O'Blyver, C. Bragg, J. Newman, R. Clucas, D. Fletcher, J. Kitson, S. McKechnie, D. Scott, and Rakiura Titi Islands Administering Body. 2009b. Guidelines for crosscultural participatory action partnerships: a case study of customary seabird harvest in New Zealand. New Zealand Journal of Zoology 36:211-241. http://dx.doi.org/10.1080/03 014220909510152

Moore, P. 2003. Seals and fisheries in the Clyde Sea area (Scotland): traditional knowledge informs science. Fisheries Research 63:51-61. http://dx.doi.org/10.1016/S0165-7836(03) $\underline{00003-1}$

Moreno, G., I. Dagorn, G. Sancho, D. Garcia, and D. Itano. 2007a. Using local ecological knowledge (LEK) to provide insight on the tuna purse seine fleets of the Indian Ocean useful 
for management. Aquatic Living Resources 20:367-376. http: //dx.doi.org/10.1051/alr:2008014

Moreno, G., L. Dagorn, G. Sancho, and D. Itano. 2007b. Fish behaviour from fishers' knowledge: the case study of tropical tuna around drifting fish aggregating devices (DFADs). Canadian Journal of Fisheries and Aquatic Science 11:1517-1528. http://dx.doi.org/10.1139/f07-113

Morrill, W. 1967. Ethnoicthyology of the Cha Cha. Ethnology 6:405-417. http://dx.doi.org/10.2307/3772827

Mow, J., E. Taylor, M. Howard, M. Baine, E. Connolly, and M. Chiquillo. 2007. Collaborative planning and management of the San Andres Archipelago's coastal and marine resources: a short communication on the evolution of the Seaflower marine protected area. Ocean and Coastal Management 50:209-222. http://dx.doi.org/10.1016/j.ocecoaman.2006.09.001

Murray, G., B. Neis, and J. Johnson. 2006. Lessons learned from reconstructing interactions between local ecological knowledge, fisheries science, and fisheries management in the commercial fisheries of Newfoundland and Labrador, Canada. Human Ecology 34:549-572. http://dx.doi.org/10.1007/s1074 5-006-9010-8

Murray, G., B. Neis, C. Palmer, and D. Schneider. 2008. Mapping cod: fisheries science, fish harvesters' ecological knowledge and cod migrations in the Northern Gulf of St. Lawrence. Human Ecology 36:581-598. http://dx.doi.org/10. $\underline{1007 / \mathrm{s} 10745-008-9178-1}$

Mymrin, N.; the Communities of Novoe Chaplino, Sireniki, Uelen, and Yanrakinnot; and H. Huntington. 1999. Traditional knowledge of the ecology of beluga whales (Delphinapterus leucas) in the northern Bering Sea, Chukotka, Russia. Arctic 52:62-70.

Nadasdy, P. 1999. The politics of TEK: Power and the integration of knowledge. Arctic Anthropology 36:1-18.

Nadasdy, P. 2003. Reevaluating the co-management success story. Arctic 56:367-380.

Nadasdy, P. 2005. The anti-politics of TEK: the institutionalization of co-management discourse and practice. Anthropologica 47:215-232.

Neis, B. 1992. Fishers' ecological knowledge and stock assessment in Newfoundland. Newfoundland Studies 8:155-178.

Neis, B. 2011. Moving forward: social-ecological interactivity, global marine change and knowledge for the future. Pages 182-199 in R. E. Ommer, R. I. Perry, K. Cochrane, and P. Cury, editors. World fisheries: a socialecological analysis. Wiley-Blackwell: Chichester, West Sussex, UK and Ames, Iowa, USA.
Neis, B., and L. Felt, editors. 2000. Finding our sea legs: linking fishery people and their knowledge with science and management. ISER Books, St. Johns, Newfoundland, Canada.

Neis, B., L. Felt, R. Haedrich, and D. Schneider. 1999. An interdisciplinary method for collecting and integrating fishers' ecological knowledge into resource management. Pages 217-235 in D. Newell and R. Ommer, editors. Fishing places, fishing people. University of Toronto Press, Toronto, Ontario, Canada.

Nelson, R. 1969. Hunters of the northern ice. University of Chicago Press, Chicago, Illinois, USA.

Nguyen, D. T., and K. Ruddle. 2010. Vietnam: the van chai system of social organization and fisheries community management. Pages 129-160 in K. Ruddle and A. Satria, editors. Managing coastal and inland waters: pre-existing aquatic management systems in Southeast Asia. Springer, New York, New York, USA. http://dx.doi.org/10.1007/978-90-481 $\underline{-9555-8 \quad 6}$

Nielsen, M. 2009. Is climate change causing the increasing narwhal (Monodon monoceros) catches in Smith Sound, Greenland? Polar Research 28:238-245. http://dx.doi.org/10. 1111/j.1751-8369.2009.00106.x

Nirmale, V., B. Sontakki, and R. S. Biradar. 2004b. Indigenous knowledge of coastal fisher-folk of Mumbai District of Maharashtra State. Karnataka Journal of Agricultural Science 17:115-118.

Nirmale, V., B. Sontakki, R. S. Biradar, and S. Metar. 2004a. Assessment of indigenous knowledge of coastal fisherfolk of greater Mumabi and Sindhudurg districts of Maharashtra. Indian Journal of Traditional Knowledge 3:27-36.

Nirmale, V., B. S. Sontakki, R. S. Biradar, S. Y. Metar, and S. L. Charatkar. 2007. Use of indigenous knowledge by coastal fisher folk of Mumbai district in Maharashtra. Indian Journal of Traditional Knowledge 6:378-382.

Noongwook G., the native village of Savoonga, the native village of Gambell, H. Huntington, and J. George. 2007. Traditional knowledge of the Bowhead Whale (Balena mysticetus) around St. Lawrence Island, Alaska. Arctic 60:47-54.

Norton, D. 2002. Coastal sea ice watch: private confessions of a convert to indigenous knowledge. Pages 126-155 in I. Krupnik and D. Jolly, editors. The Earth is faster now: indigenous observations of Arctic environmental change. ARCUS, Fairbanks, Alaska, USA.

Nsiku, E. 2007. Indigenous technical knowledge of Malawian artisanal fisheries. Pages 83-102 in N. Haggan, B. Neis, and I. Baird, editors. Fishers' knowledge in fisheries science and management. UNESCO, Paris, France. 
Obura, D., S. Wells, J. Church, and C. Horrill. 2002. Monitoring of fish and fish catches by local fishermen in Kenya and Tanzania. Marine and Freshwater Research 53:215-222. http://dx.doi.org/10.1071/MF01151

O'Connor L., and P. Kroefges. 2008. The land remembers: landscape terms and place names in Lowland Chontal of Oaxaca, Mexico. Language Sciences 30:291-315. http://dx.do i.org/10.1016/j.langsci.2006.12.007

Olsson, P., and C. Folke. 2001. Local ecological knowledge and institutional dynamics for ecosystem management: a study of Lake Racken watershed, Sweden. Ecosystems 4:85-104.

Paine, R. 1957. Coast Lapp society. Troms $\emptyset$ Museums skrifter, v. 4. Troms $\varnothing$ Museum Press, Troms $\varnothing$, Norway.

Palmer, C. 1994. Are folk management practices models for formal regulations? Evidence from the lobster fisheries of Newfoundland and Maine. Pages 237-249 in C. Dyer and J. McGoodwin, editors. Folk management of the world's fisheries: lessons for modern fisheries management. University of Colorado Press, Niwot, Colorado, USA.

Palmer, C., and R. Wadley. 2007. Local environmental knowledge, talk and skepticism: using 'LES' to distinguish 'LEK' from 'LET' in Newfoundland. Human Ecology 35:749-760. http://dx.doi.org/10.1007/s10745-006-9108-z

Pearce, T., J. Ford, G. Laidler, B. Smit, F. Duerden, M. Allarut, M. Andrachuk, S. Baryluk, A. Dialla, P. Ellee, A. Goose, T. Ikummaq, E. Joamie, F. Kataoyak, E. Loring, S. Meaking, S. Nickels, K. Shappa, J. Shirley, and J. Wandel. 2009. Community collaboration and climate change research in the Canadian Arctic. Polar Research 28:10-27. http://dx.doi.org/ 10.1111/j.1751-8369.2008.00094.x

Pearce, T., H. Wright, R. Notaina, A. Kudlak, B. Smit, J. Ford, and C. Furgal. 2011. Transmission of environmental knowledge and land skills among Inuit men in Ulakhaktok, Northwest Territories, Canada. Human Ecology 39 (3):271-288. http://dx.doi.org/10.1007/s10745-011-9403-1

Poepoe, K., P. Bartram, and A. Friedlander. 2007. The use of traditional knowledge in the contemporary management of a Hawaiian community's marine resources. Pages 328-339 in N. Haggan, B. Neis, and I. Baird, editors. Fishers' knowledge in fisheries science and management. UNESCO, Paris, France.

Poizat, G., and E. Baran. 1997. Fishermen's knowledge as background information in tropical fish ecology: a quantitative comparison with fish sampling results. Environmental Biology of Fishes 50:435-449. http://dx.doi.org/10.1023/A:1007317423165

Power, A., and D. Mercer. 2003. The role of fishers' knowledge in implementing Ocean Act initiatives in Newfoundland and
Labrador. Pages 20-25 in N. Haggan, C. Brignall, and L. Wood, editors. Putting fishers' knowledge to work, conference proceedings (27-30 August 2011, Vancouver, Canada). Fisheries Centre Research Reports 11:1.

Price, B., and R. Rulifson. 2004. Use of traditional ecological knowledge to reduce striped bass bycatch in the Currituck Sound white perch gill-net fishery. North American Journal of Fisheries Management 24:785-792. http://dx.doi.org/10.15 77/M03-124.1

Pulsifer, P., G. Laidler, D. R. F. Taylor, and A. Hayers. 2011. Towards an indigenist data management program : reflections on experiences developing an atlas of sea ice knowledge and use. Canadian Geographer 55:108-124. http://dx.doi.org/10. 1111/j.1541-0064.2010.00348.x

Rajamani, L., and H. Marsh. 2010. Using parallel regionaland local-scale initiatives to inform conservation management of rare wildlife: a case study of the dugong Dugong dugon in Sabah, Malaysia. Endangered Species Research 13:17-23. http://dx.doi.org/10.3354/esr00310

Rasalato, E., V. Maginnity, and J. Brunnschweiler. 2010. Using local ecological knowledge to identify shark river habitats in Fiji (South Pacific). Environmental Conservation 37:90-97. http://dx.doi.org/10.1017/S0376892910000317

Rathakrishnan, T., M. Ramasubramanian, N. Anandaraja, N. Suganthi, and S. Anitha. 2009. Traditional fishing practices followed by fisher folks of Tamil Nadu. Indian Journal of Traditional Knowledge 8:543-547.

Reyes-Garcia, V., V. Vadez, T. Huanca, W. Leonard, and T. McDade. 2007. Economic development and local ecological knowledge: a deadlock? Quantitative research from a native Amazonian society. Human Ecology 35:371-377. http://dx.do i.org/10.1007/s10745-006-9069-2

Richmond, R., T. Rongo, Y. Golbuu, S. Victor, N. Idechong, G. Davis, W. Kostka, L. Neth, M. Hamnett, and E. Wolanski. 2007. Watersheds and coral reefs: conservation science, policy and implementation. BioScience 57:598-608.

Riewe, R. 1991. Inuit use of the sea ice. Arctic and Alpine Research 23:3-10. http://dx.doi.org/10.2307/1551431

Riewe, R., and J. Oakes. 2006. Climate change: linking traditional and scientific knowledge. University of Manitoba, Aboriginal Issues Press, Winnipeg, Manitoba, Canada.

Roberts, C. 2007. The unnatural history of the sea. Island Press, Washington D.C., USA.

Rosa, I., R. Alves, K. Bonifacio, J. Mourao, F. Osorio, T. Oliveira, and M. Nottingham. 2005. Fishers' knowledge and seahorse conservation in Brazil. Journal of Ethnobiology and Ethnomedicine 1:12-27. http://dx.doi.org/10.1186/1746-4269-1-12 
Rosenberg, A., J. Bolster, K. Alexander, W. Leavenworth, A. Copper, and M. McKenzie. 2005. The history of ocean resources: modeling cod biomass using historical records. Frontiers in Ecology and Environment 3:84-90. http://dx.doi. org/10.1890/1540-9295(2005)003[0078:THOORM]2.0.CO;2

Ruddle, K. 1994. Local knowledge in the folk management of fisheries and coastal marine environments. Pages 161-206 in C. Dyer and J. McGoodwin, editors. Folk management of the world's fisheries: lessons for modern fisheries management. University Press of Colorado, Niwot, Colorado, USA.

Sadovy, Y., and W. Cheung. 2003. Near extinction of a highly fecund fish: the one that nearly got away. Fish and Fisheries 4:86-99. http://dx.doi.org/10.1046/j.1467-2979.2003.00104.x

Saenz-Arroyo, A., C. Roberts, J. Torre, and M. Carino-Olvera. 2005a. Using fishers' anecdotes, naturalists' observations and grey literature to reassess marine species at risk: the case of the Gulf grouper in the Gulf of California, Mexico. Fish and Fisheries 6:121-133. http://dx.doi.org/10.1111/j.1467-2979.2 005.00185.x

Saenz-Arroyo, A., C. M. Roberts, J. Torre, M. Cariño-Olvera, and R. R. Enríquez-Andrade. 2005b. Rapidly shifting environmental baselines among fishers of the Gulf of California. Proceedings of the Royal Society $B$ 272:1957-1962. http://dx.doi.org/10.1098/rspb.2005.3175

Satria, A. 2007. Sawen: institution, local knowledge and myth in fisheries management in North Lombok, Indonesia. Pages 199-220 in N. Haggan, B. Neis, I. Baird, editors. Fishers' knowledge in fisheries science and management. UNESCO, Paris, France.

Satria, A., and D. Adhuri. 2010. Pre-existing fisheries management systems in Indonesia, focusing on Lombok and Maluku. Pages 31-55 in K. Ruddle and A. Satria, editors. Managing coastal and inland waters: pre-existing aquatic management systems in southeast Asia. Springer, New York, New York, USA. http://dx.doi.org/10.1007/978-90-481-9555-8 2

Schafer, A., and G. Reis. 2008. Artisanal fishing areas and traditional ecological knowledge: the case study of artisanal fisheries of the Patos Lagoon estuary (Brazil). Marine Policy 32:283-292. http://dx.doi.org/10.1016/j.marpol.2007.06.001

Schlacher, T., A. Lloyd, and A. Wiegand. 2010. Use of local ecological knowledge in the management of algal blooms. Environmental Conservation 37:210-221. http://dx.doi.org/10 $\underline{.1017 / \mathrm{S} 0376892910000305}$

Scholz, A., K. Bonzon, R. Fujita, N. Benjamin, N. Woodling, P. Black, P., and C. Steinback. 2004. Participatory socioeconomic analysis: drawing on fishermen's knowledge for marine protected area planning in California. Marine Policy 28:335-349. http://dx.doi.org/10.1016/j.marpol.2003.09.003

Senft, G. 2008. Landscape terms and place names in the Trobriand Islands-the Kaile'una subset. Language Sciences 30:340-361. http://dx.doi.org/10.1016/j.langsci.2006.12.001

Shackeroff, J., L. Campbell, and L. Crowder. 2011. Socioecological guilds: putting people into marine historical ecology. Ecology and Society 16(1): 52. [online] URL: http:// www.ecologyandsociety.org/vol16/iss1/art52/.

Shepert, M. 2008. Oral history and traditional ecological knowledge. Pages 205-22 in K. Culver and D. Castle, editors. Aquaculture, innovation and social transformation. Springer, Dordrecht, Netherlands.

Silvano, R., and A. Begossi. 2005. Local knowledge on a cosmopolitan fish: ethnoecology of Pomatomus saltatriz (Pomatomidae) in Brazil and Australia. Fisheries Research 71:43-59. http://dx.doi.org/10.1016/j.fishres.2004.07.007

Silvano R., P. MacCord, R. Lima, and A. Begossi. 2006. When does the fish spawn? Fishermen's local knowledge of migration and reproduction of Brazilian coastal fishes. Environmental Biology of Fish 76:371-386. http://dx.doi.org/ 10.1007/s10641-006-9043-2

Silvano, R., and J. Valbo-Jorgensen. 2008. Beyond fishermen's tales: contributions of fishers' local ecological knowledge to fish ecology and fisheries management. Environment, Development and Sustainability 10:657-675. http://dx.doi.org/10.1007/s10668-008-9149-0

Silver, J., and L. Campbell. 2005. Fisher participation in research: dilemmas with the use of fisher knowledge. Ocean and Coastal Management 48:721-741. http://dx.doi.org/10.10 16/j.ocecoaman.2005.06.003

Simpson, L. 2004. Anticolonial strategies for the recovery and maintenance of indigenous knowledge. American Indian Quarterly 28:373-385. http://dx.doi.org/10.1353/aiq.2004.0107

Sloan, N. A., and P. M. Barthier. 2009. Historic marine invertebrate species inventory: case study of a science baseline towards establishing a marine conservation area. Aquatic Conservation: Marine and Freshwater Ecosystems 19:827-837. http://dx.doi.org/10.1002/aqc.1019

St. Martin, K., and M. Hall-Arber. 2008. The missing layer: geo-technologies, communities and implications for marine spatial planning. Marine Policy 32:779-786. . http://dx.doi.or $\mathrm{g} / 10.1016 / \mathrm{j} . \mathrm{marpol} .2008 .03 .015$ 
Swezey, S., and R. Heizer. 1984. Ritual regulation of andromous fish resources in native California. In B. Gunda, editor. The fishing cultures of the world: studies in ethnology, cultural ecology and folklore. Akademiai Kiado, Budapest, Hungary.

Szuster, W. B and H. Albasri. 2010. Site selection for grouper mariculture in Indonesia. International Journal of Fisheries and Aquaculture 2(3):87-92

Terry, J., and S. Etienne. 2011. "Stones from the dangerous winds": reef platform mega-clasts in the tropical Pacific Islands. Natural Hazards 56:567-569. http://dx.doi.org/10.1007/ s11069-010-9697-0

Thornton, T. F. 2008. Being and place among the Tlingit. University of Washington Press, Seattle, Washington, USA.

Thornton, T. F. 2011. Language and landscape among the Tlingit. Pages 275-289 in D. M. Mark, A. G. Turk, N. Burenhult, and D. Stea, editors, Landscape in language: transdisciplinary perspectives. John Benjamins Publishing Co., Amsterdam, Netherlands, and Philadelphia, Pennsylvania, USA.

Thornton, T. F. 2012. Watersheds and marinescapes: understanding and maintaining cultural diversity among southeast Alaska Natives. Pages 123-136 in B. R. Johnston, L. Hiwasaki, I. J. Klaver, A. Ramos Castillo, and V. Strang, editors. Water, cultural diversity, and global environmental change: emerging trends and sustainable futures? UNESCO, Paris, France. http://dx.doi.org/10.1007/978-94-007-1774-9 9

Thornton, T. F., and H. Kitka Sr. 2010. The Tlingit way of conservation: a matter of respect. Pages 211-219 in K. Walker Painemilla, A. Rylands, A. Woofter, and C. Hughes, editors. Indigenous peoples and conservation: from rights to management. Conservation International, Arlington, Virginia, USA.

Thornton, T. F., M. Moss, V. Butler, J. Hebert, and F. Funk. 2010. Local and traditional knowledge and the historical ecology of Pacific herring in Alaska. Journal of Ecological Anthropology 14:81-88.

Thornton, T. F., M. Moss, V. Butler, F. Funk, J. Hebert, and W. Culp. 2009. Herring synthesis: documenting and modeling herring spawning areas within socio-ecological systems over time in the southeastern Gulf of Alaska. Project \#728. North Pacific Research Board, Anchorage Alaska, USA. [online] URL: http://herringsynthesis.research.pdx.edu/

Tobisson, E., J. Andersson, Z. Ngazi, L. Rudberg, and U. Cederlof. 1998. Tides, monsoons and seabed: local knowledge and practice in Chwaka Bay, Zanzibar. Ambio 27:677-685.

Tremblay, M., C. Furgal, C. Larrivee, T. Annanack, P. Tookalook, M. Qiiski, E. Angiyou, N. Swappie, J. Savard, and
M. Barrett. 2008. Climate change in northern Quebec: adaptation strategies from community-based research. Arctic S61:27-34.

Turnbull, D. 1997. Reframing science and other local knowledge traditions. Futures 29:551-562. http://dx.doi.org/1 $\underline{\text { 0.1016/S0016-3287(97)00030-X }}$

Turner, N., and F. Berkes. 2006. Coming to understanding: developing conservation through incremental learning in the Pacific Northwest. Human Ecology 34:495-513. http://dx.doi. org/10.1007/s10745-006-9042-0

Turner, N., and H. Clifton. 2006. The forest and the seaweed: Gitga'at seaweed, traditional ecological knowledge and community survival. Pages 66-86 in C. Menzies, editor. Traditional ecological knowledge and natural resource management. University of Nebraska Press, Lincoln, Nebraska, USA.

Valdés-Pizzini, M., and C. García-Quijano. 2009. Coupling of humans, habitats and other species: a study of the fishers' traditional ecological knowledge (TEK) in La Parguera. Caribbean Journal of Science 45:363-371.

Vayda, A. P., and B. B. Walters. 1999. Against political ecology. Human Ecology 27:167-179. http://dx.doi.org/10.1023/ A:1018713502547

Venkatachalam, A. J., A. R. G. Price, S. Chandrasekara, S. Senaratna Sellamuttu, and J. Kaler. 2010. Changes in frigate tuna populations on the south coast of Sri Lank: evidence of the shifting baseline syndrome from analysis of fisher observations. Aquatic Conservation: Marine and Freshwater Ecosystems 20:167-176. http://dx.doi.org/10.1002/aqc.1068

Walters B., P. Ronnback, J. Kovacs, B. Crona, S. Hussain, R. Badola, J. Primavera, E. Barbier, and F. Dahdouh-Guebas. 2008. Ethnobiology, socio-economics and management of mangrove forests: a review. Aquatic Botany 89:220-236. http ://dx.doi.org/10.1016/j.aquabot.2008.02.009

Warner, G. 1997. Participatory management, popular knowledge, and community empowerment: the case of sea urchin harvesting in the Vieux-Fort area of St. Lucia. Human Ecology 25:29-47. http://dx.doi.org/10.1023/A:1021931802531

Watson, A., and O. H. Huntington. 2008. They're here-I can feel them: the epistemic spaces of indigenous and Western knowledges. Social and Cultural Geography 9:257-281. http ://dx.doi.org/10.1080/14649360801990488

Wehi, P. 2009. Indigenous ancestral sayings contribute to modern conservation partnerships: examples using Phormium tenax. Ecological Applications 19(1):267-75. [online] URL: http://www.ncbi.nlm.nih.gov/pubmed/19323188 
Wenzel, G. 1999. Traditional ecological knowledge and Inuit: reflections on TEK research and ethics. Arctic 52:113-124.

Wilson, D., J. Raakjaer, and P. Degnbol. 2006. Local ecological knowledge and practical fisheries management in the tropics: a policy brief. Marine Policy 30:794-801. http://d x.doi.org/10.1016/j.marpol.2006.02.004

Wohlforth, C. 2005. The whale and the supercomputer: on the northern front of climate change. Farrar, Strauss, and Giroux, New York, USA.

Wroblewski, J., T. Bell, A. Copeland, E. Edinger, C. Yu Feng, J. Saxby, D. Schneider, and J. Simms. 2009. Toward a sustainable Iceland scallop fishery in Gilbert Bay, a marine protected area in the eastern Canada coastal zone. Journal of Cleaner Production 17:424-430. http://dx.doi.org/10.1016/j.j clepro.2008.08.004

Wyllie-Echeverria, S., K. Gunnarsson, M. Mateo, J. Borg, P. Renom, J. Kuo, A. Schanz, F. Hellblom, E. Jackson, G. Pergent, C. Pergent-Martini, M. Johnson, J. Sanchez-Lizaso, C. Boudouresque, and K. Aioi. 2002. Protecting the seagrass biome: report from the traditional seagrass knowledge working group. Bulletin of Marine Science 71:1415-1417.

Zavaleta, E. 1999. The emergence of waterfowl conservation among Yup'ik hunters in the Yukon-Kuskokwin Delta, Alaska. Human Ecology 27:231-267. http://dx.doi.org/10.1023/ A:1018773211034

Zurba, M. 2009. Bringing local synthesis into governance and management systems: the Girringun TUMRA case in Northern Queensland, Australia. Journal of the Royal Society of New Zealand 39:179-182. http://dx.doi.org/10.1080/03014 $\underline{220909510575}$ 